\title{
Atrial Fibrillation Drivers: Redefining the Electrophysiological Substrate
}

\section{New Mechanistic Insights in AF Induction, Maintenance, and Reduction}

Short Title: Redefining Atrial Fibrillation Drivers

Markus Rottmann, Ph.D., Anna Pfenniger MD-Ph.D., Shin Yoo, Ph.D., David Johnson, Gail Elizabeth Geist, Suman Mandava, Amy Burrell, Bradley P. Knight, MD, Rod Passman, MD and Rishi Arora, MD.

Feinberg Cardiovascular and Renal Research Institute, Northwestern University Feinberg School of Medicine, Chicago, IL

Corresponding author: Rishi Arora, MD

657 N St Clair Street, Chicago, IL 60611

Phone: +1 (312) 664-3278, Fax: +1 (312) 695-3278

E-Mail: $\underline{\text { r-arora@northwestern.edu }}$

Word count: 11445

Subject Terms: Arrhythmias, Atrial Fibrillation, Cardiac Electrophysiology, High-Density Mapping, Catheter Ablation, Pulmonary Vein Isolation, Fibrosis 


\section{ABBREVIATION}

$31 \quad$ ACT

32 AF

33 ANOVA

$34 \mathrm{CL}$

$35 \mathrm{CV}$

36 DF

37 EGM

$38 \quad \mathrm{FI}$

39 LA

40 LAA

41 LAFW

42 LAT

43 O

44 pi

45 PLA

46 PRA

47 RA

48 RAA

49 RAP

50 RAFW

51 RotA

52 RP

53 PV

$54 \quad$ PVI

55 PS

56 SD

57 SEM

58 ShEn
Activated clotting time

Atrial fibrillation

Analysis of variance

Cycle length

Conduction velocity

Dominant Frequency

Electrogram

Fractionation Interval

Left atrium

Left atrial appendage

Left atrial free wall

Local activation time

Organization Index

Probability of an amplitude value occurring in bin $\mathrm{i}$

Posterior left atrium

Posterior right atrium

Right atrium

Right atrial appendage

Rapid atrial pacing

Right atrial free wall

Rotational activity

Refractory period

Pulmonary vein

Pulmonary vein isolation

Phase singularity

Standard deviation

Standard error of the mean

Shannon's entropy 
medRxiv preprint doi: https://doi.org/10.1101/2020.12.14.20248171; this version posted December 16, 2020. The copyright holder for this preprint (which was not certified by peer review) is the author/funder, who has granted medRxiv a license to display the preprint in perpetuity. All rights reserved. No reuse allowed without permission. 
medRxiv preprint doi: https://doi.org/10.1101/2020.12.14.20248171; this version posted December 16, 2020. The copyright holder for this preprint (which was not certified by peer review) is the author/funder, who has granted medRxiv a license to display the preprint in perpetuity.

All rights reserved. No reuse allowed without permission.

ABSTRACT

61 Background: We performed high-density mapping of persistent atrial fibrillation (AF) in animals and patients (1) to test that $A F$ is due to $\geq 1$ reentries, and (2) to characterize activation delay and reentries pre/ post pulmonary vein isolation (PVI). We determined electrophysiological characteristics that may predispose to the induction, maintenance, and reduction of AF.

Methods and Results: This study includes 48 dogs and nine patients. 43 AF- and five sinus/ paced rhythm dogs (3-14 weeks rapid atrial pacing) were studied at open chest surgery with 117 epicardial electrograms (EGMs) (2.5mm dist.) in 6 bi-atrial regions. Rotational activity automatically detected with a new algorithm tracking the earliest and latest activation in all regions ( $5 \pm 2$ per region) were stable over $424 \pm 505 \mathrm{~ms}$ [120$4940 \mathrm{~ms}]$. Reentry stability was highest in the right atrial appendage (RAA) $(405 \pm 219 \mathrm{~ms})$ and the posterior left atrium (PLA) $(267 \pm 115 \mathrm{~ms})$ and anchored between $>=3$ zones of activation delay $(15 \pm 5 \mathrm{~ms}$, median $13 \mathrm{~ms}$ ) defined as $>10 \mathrm{~ms}$ per $2.5 \mathrm{~mm}$. Cycle length $(C L)$ and degree of focal fibrosis were highest in the PLA and left atrial free wall (LAFW) with $94 \pm 7 \mathrm{~ms}, 96 \pm 5 \mathrm{~ms}$, and $49 \pm 14 \%, 47 \pm 19 \%$. Fiber crossing density correlated with the stability of rotational activity $(R=0.6, P<0.05)$. Activation delay was $2 x$ higher in $A F$ compared to sinus rhythm/paced rhythm (interval $200-500 \mathrm{~ms}$ ). Activation delay zones $>10 \mathrm{~ms}$ were at the same locations, but increased $4 x$ during AF vs. SR and were located at fiber crossings, fibrosis/ fat zones. Stability of rotational activity correlated with Organization Index (OI), Fraction Index (FI), Shannon's Entropy (ShEn), and CL ( $\mathrm{R}>0.5, \mathrm{p}<0.0001)$. PVI in five hearts increased $C L[2-14 \%]$ and reduced stability of rotational activity in nearly all regions remote to the pulmonary veins (PVs). Also in the clinical evaluation in nine patients using the HD-catheter (16 electrodes, $3 \mathrm{~mm}$ dist.) activation delay at the reentrant trajectory was $2 x$ higher at edges with maximal delay $(20.5 \pm 8.1 \mathrm{~ms}$, median $19.6 \mathrm{~ms})$ vs $(9.3 \pm 8.8 \mathrm{~ms}$, median $9.2 \mathrm{~ms})$ and $1.4 \mathrm{x}$ higher during AF $(13.0 \pm 18.7 \mathrm{~ms}$, median $7.2 \mathrm{~ms})$ compared to SR/ CS-pacing $(18.0 \pm 11.6 \mathrm{~ms}$,

82 median $17.7 \mathrm{~ms})$.

Conclusion: Rotational activities in all bi-atrial regions anchored between small frequency-dependent activation delay zones in AF. PVI led to beneficial remodeling in bi-atrial regions remote to the PVs. These data may identify a new paradigm for persistent AF. 
medRxiv preprint doi: https://doi.org/10.1101/2020.12.14.20248171; this version posted December 16, 2020. The copyright holder for this preprint (which was not certified by peer review) is the author/funder, who has granted medRxiv a license to display the preprint in perpetuity.

\section{Clinical Perspective}

90

91 What Is New?

92 - Rotational activity trajectories based on high-resolution mapping follow propagation line

93 patterns.

94 - Rotational activities anchor frequently between small frequency-dependent slow conduction 95 zones in all bi-atrial regions.

96 - Slow conduction zones are fiber crossings zones and develop into fibrosis and fat regions 97 over time.

98 - PVI reduces slow conduction zones and AF drivers in regions remote to the PVs in both atria.

99 What Are the Clinical Implications?

100 - The new method for the robust detection of rotational activity based on the earliest and 101 latest activation may be useful for an improved AF treatment.

102 - Stability of rotational activity may be predicted with the correlated substrate characteristic

103 fiber crossings density, with slow conduction zones, and with established electrogram

104 measures in the different atrial regions.

105 - PVI leads to beneficial remodeling in all regions remote to the PVs in the left atrium and right 106 atrium.

107

108 
medRxiv preprint doi: https://doi.org/10.1101/2020.12.14.20248171; this version posted December 16, 2020. The copyright holder for this preprint (which was not certified by peer review) is the author/funder, who has granted medRxiv a license to display the preprint in perpetuity.

\section{INTRODUCTION}

111 The multiple wavelet reentry hypothesis as a mechanism for atrial fibrillation (AF) was proposed

112 by Moe and Abildskov in $1959 .^{1}$ In 1985, Allessie experimentally confirmed this hypothesis

113 showing that multiple wavefronts throughout the atrium maintain themselves by reentry around

114 continuously shifting areas of functional conduction block. ${ }^{2}$ In 1998 , Haïssaguerre demonstrated

115 in his seminal paper that pulmonary veins (PV) triggers can be critical for the initiation of $A F$ and

$116 \mathrm{PVI}$ can reduce the occurrence of $\mathrm{AF}^{3}{ }^{3}$ However, despite extensive research, the mechanisms of

117 AF are still not clear. ${ }^{4,5}$ The present work aimed to determine electrophysiological characteristics

118 both in a human-like large animal AF model and in AF patients that may facilitate the occurrence

119 of local arrhythmias. Many mapping studies aimed to test the hypothesis that AF is caused by

120 either focal or reentrant drivers in AF using atrial electrograms (EGMs) based on sequential or

121 simultaneous multisite site mapping at the endocardium and epicardium using different types

122 and numbers of electrodes. ${ }^{6-19}$ Several studies showed that reentry circuits can drive AF, that

123 slow conduction leads to reentry in $\mathrm{AF}$ and that $\mathrm{PVI}$ reduces $\mathrm{AF} .{ }^{20}$ Although the overall association

124 between areas of slow conduction and AF drivers is evident, several issues remain unsettled

125 (Figure $1 \mathrm{~A}$ ) including:

126 What are the regional differences in rotational activities and activation delay zones?

$1272 . \quad$ Is there a critical activation delay and size threshold during AF that can differentiate tissue

128 regions producing stable reentry from those that do not?

129 3. What is the shape of the reentrant trajectory based on high-resolution mapping data?

1304 4. Is the stability of rotational activity correlated with slow conduction zones, established

131 electrogram measures, and substrate characteristics? 
medRxiv preprint doi: https://doi.org/10.1101/2020.12.14.20248171; this version posted December 16, 2020. The copyright holder for this preprint (which was not certified by peer review) is the author/funder, who has granted medRxiv a license to display the preprint in perpetuity.

All rights reserved. No reuse allowed without permission.

$132 \quad 5 . \quad$ What are the effects of PVI rotational activity and slow conduction zones on regions in

133 both atria remote to the pulmonary veins?

134 6. Are slow conduction zones similar in animals and patients during AF and SR/ paced

135 rhythm?

136 This study aimed to answer these questions in a canine model and patients of persistent AF.

138 METHODS

139 An expanded materials and methods can be found in the supplementary material online 140 Supplementary Data.

\section{Animals and Experimental Rapid Atrial Pacing Protocol}

143 We induced AF in 43 hound dogs by rapid atrial pacing (RAP) (600 beats/min) for 3-8 weeks. In

144 five dogs we also performed PVI. Before all the procedures, animals were premedicated with

145 acepromazine $(0.01-0.02 \mathrm{mg} / \mathrm{kg}$, Vedco) and induced with propofol ( $3-7 \mathrm{mg} / \mathrm{kg}$, Zoetis). All

146 experiments were performed under general anesthesia (inhaled) with isoflurane (1-3 \%).

147 Adequacy of anesthesia was assessed by toe pinch and palpebral reflex. The Animal Care and Use

148 Committee of Northwestern University approved this experimental protocol. The protocol is in

149 line with the Guide for the Care and Use of Laboratory Animal (US National Institutes of Health

150 Publication). Detailed methods are given in the Data Supplement. For pacemaker insertion, the

151 right jugular vein was accessed by direct cutdown and ligated distally. A bipolar screw-in

152 Medtronic pacing lead was inserted through an incision in the right jugular vein. The tip of the 
medRxiv preprint doi: https://doi.org/10.1101/2020.12.14.20248171; this version posted December 16, 2020. The copyright holder for this preprint (which was not certified by peer review) is the author/funder, who has granted medRxiv a license to display the preprint in perpetuity. All rights reserved. No reuse allowed without permission.

153 lead was fluoroscopically placed and fixed in the RA appendage after confirming an adequate

154 capture threshold ( $<0.5 \mathrm{mV}$ with a pulse width of $0.4 \mathrm{~ms}$ ). The proximal end of the pacing lead

155 was connected to a custom-modified Medtronic programmable pulse generator that was

156 subsequently implanted in a subcutaneous pocket in the neck. After all the incisions were closed,

157 the dogs were allowed to recover from anesthesia and were returned to the animal quarters.

158 After confirming an adequate threshold for atrial capture ( $<0.5 \mathrm{mV}$ with pulse width $0.4 \mathrm{~ms})$,

159 rapid atrial pacing was performed incrementally over 1-3 days until adequate capture was

160 confirmed at $600 \mathrm{bpm}$. The pacing was continued for 3-14 weeks until persistent AF was induced.

162 High-Density Mapping During Open Chest Surgery

163 Atrial epicardial mapping studies were performed during open-heart surgery in AF on the beating

164 heart. High-resolution mapping was performed with the UnEmap mapping system ( University of

165 Auckland, Auckland, New Zealand) which consists of a triangular mapping plaque and records

166117 bipolar electrogram signals $(1 \mathrm{kHz}$ sampling rate, 117 electrodes, interelectrode distance of

$1672.5 \mathrm{~mm}$ ) covering a total area of $7.3 \mathrm{~cm}^{2}$ on the atrial epicardial surface. Bipolar electrograms

168 were recorded from six different regions in both atria: posterior left atrium (PLA), left atrial free

169 wall (LAFW), left atrial appendage (LAA), posterior right atrium (PRA), right atrial free wall

170 (RAFW), and right atrial appendage (RAA) (Figure 1B, Supplemental Figure S1-S13). Data were

171 digitally recorded and processed with the UnEmap mapping system software. Data were

172 collected with the GE Prucka Cardiolab system (GE Healthcare), and two rectangular mapping

173 plaques with 12 electrodes ( $3 \times 4$ electrodes, interelectrode distance $5 \mathrm{~mm}$ ). The data were

174 transferred and stored on a personal computer for further analysis. The AF EGM measures 
medRxiv preprint doi: https://doi.org/10.1101/2020.12.14.20248171; this version posted December 16, 2020. The copyright holder for this preprint (which was not certified by peer review) is the author/funder, who has granted medRxiv a license to display the preprint in perpetuity.

All rights reserved. No reuse allowed without permission.

175 including Dominant Frequency (DF), Organization Index (OI), Fractionation Interval (FI),

176 Shannon's Entropy (ShEn) were calculated with in-house MATLAB (MatLab, Mathworks, Natick

177 MA) programs. We excluded electrodes (< 10\%) with inadequate quality due to noise or poor

178 contact. The sequential activation maps of persistent AF were constructed for 10 consecutive

179 seconds in each atrial region in all hearts. The data were analyzed automatically for activation

180 times using in-house MATLAB programs by detecting the steepest negative slope in the bipolar

181 electrograms. ${ }^{21}$

182

183 Electrogram Measures

184 Cycle Length (CL) -

$185 \mathrm{CL}$ was calculated with the steepest negative slope using the maximal negative slope of the

186 bipolar electrogram.

187 Dominant Frequency (DF) -

188 DF has been shown to correspond to rotational activity in AF. ${ }^{22,}{ }^{23}$ Dominant frequency was

189 calculated with the highest power in the power spectrum using the fast Fourier transform and

190 bandpass filtering with cutoff frequencies of 40 and $250 \mathrm{~Hz}$.

191 Organization Index (OI) -

192 Ol is a frequency domain parameter of the temporal organization or regularity. ${ }^{24,}{ }^{25}$ Ol was

193 computed as the area under $1-\mathrm{Hz}$ windows of the DF peak, and the next 3 harmonic peaks divided

194 by the total area of the spectrum from $3 \mathrm{~Hz}$ up to the fifth harmonic peak. ${ }^{24,25}$

195 Fractionation Interval (FI) -

$196 \mathrm{Fl}$ is the mean interval between deflections detected in the bipolar signal segment. ${ }^{26}$ Deflections 
medRxiv preprint doi: https://doi.org/10.1101/2020.12.14.20248171; this version posted December 16, 2020. The copyright holder for this preprint (which was not certified by peer review) is the author/funder, who has granted medRxiv a license to display the preprint in perpetuity. All rights reserved. No reuse allowed without permission.

197 were defined with the following conditions: (a) the bipolar peak-to-peak amplitude was greater

198 than a defined noise level, (b) the time between a neighbored positive peak and the negative

199 peak was within a 10 ms window, and (c) the detected deflection did not overlap within 50 ms

200 with another detected deflection. The noise level was determined by the amplitude level, which

201 avoids the detection of noise-related deflections in the iso-electric portions of the signal.

202 Shannon Entropy (ShEn) -

203 ShEn is a measure of the complexity of the EGMS. ${ }^{27}$ Amplitude values of each EGM segment (3908

204 or 4000 amplitudes, $1 \mathrm{kHz}$, or $977 \mathrm{~Hz}$ sample rate) were calculated, and these were binned into

2051 of 29 bins with a width of 0.125 standard deviation (SDs). ShEn was calculated using the

206 following formula, with $p_{i}$ the probability of an amplitude value occurring in bin $\mathrm{i}$.

$$
\text { ShEn }=\frac{-\sum_{i=1}^{29} p_{i} \log _{10} p_{i}}{\log _{10} p_{i}}
$$

Detection of Slow Conduction Regions -

209 Conduction velocity cannot be measured from epicardial mapping alone as it may not include the

210 entire pathway of the wavefront between 2 points; we, therefore, used the term activation delay

211 to describe this measure. To quantify changes in epicardial activation delay objectively and

212 reproducibly, all electrogram data including its geometric coordinates were imported into

213 MatLab, and a proprietary code was written for automated calculation of epicardial activation

214 delay. To correlate epicardial activation during AF, the epicardial maps were partitioned into

215 small and fixed regions of interest (ROIs) of $2.5 \mathrm{~mm} \times 2.5 \mathrm{~mm}$, and the activation delay in each

216 ROI during AF was automatically measured. 
medRxiv preprint doi: https://doi.org/10.1101/2020.12.14.20248171; this version posted December 16, 2020. The copyright holder for this preprint (which was not certified by peer review) is the author/funder, who has granted medRxiv a license to display the preprint in perpetuity. All rights reserved. No reuse allowed without permission.

219 In the literature, the trajectory of reentries is calculated based on phase singularities. ${ }^{20,} 28,29$

220 However, this method has several limitations for robust detection and can falsely detect phase

221 singularities in the absence of rotors. ${ }^{30}$ In the present work, a completely new method was

222 developed to detect the trajectory of rotational activity more robustly. Reentry was detected

223 based on activation time maps showing 360-degree rotations using both, earliest and latest

224 activation $x, y$-locations in the activation time maps over time. Multiple activation time maps

225 were calculated in $5 \mathrm{~ms}$ steps over 10 seconds. In each of these local activation time (LAT) maps

226 the position of the earliest activation and the position of the latest activation was marked. If

227 these detected locations of earliest and latest activation correlated over time with repetitive

228 patterns showing loops, these activation patterns were considered as rotational activities. The

229 computer program was written in a proprietary code in MatLab. The reentry stability was

230 assessed as the duration of observed reentrant activity over time. Additional manual annotation

231 of 360-degree rotations in local activation time maps was used for confirmation of the automatic

232 detections of rotational activities. And the results of this new method were compared to a

233 previously described method based on phase singularity detections based on the Hilbert phase

234 and sinusoidal recomposition. ${ }^{31}$ In addition to reentries, also focal activities were automatically

235 detected. Focal activities and their dimensions were detected as simultaneous earliest activities

236 within activation time maps in five msec time steps.

238 Pulmonary Vein Isolation and Remapping-

239 In the open chest model, pulmonary vein isolation was performed on the epicardium with an 240 isolator synergy ablation clamp (AtriCure Synergy, AtriCure, Inc., Cincinnati, OH) for bipolar 
medRxiv preprint doi: https://doi.org/10.1101/2020.12.14.20248171; this version posted December 16, 2020. The copyright holder for this preprint (which was not certified by peer review) is the author/funder, who has granted medRxiv a license to display the preprint in perpetuity. All rights reserved. No reuse allowed without permission.

241 radiofrequency energy lesions. The Atricure system includes a bipolar RF clamp and an RF

242 generator. Lines of conduction block were generated by RF energy delivery (75 volts, 750

243 milliamps) to the atrial tissue compressed between the jaws of the clamp. Energy delivery was

244 continued until the lesion was transmural, indicated by steady and reduced conductance

245 between electrodes in the clamp. Post PVI, epicardial mapping was performed again in all bi-

246 atrial regions with the high-resolution mapping plaque.

248 Tissue Analysis

249 We further performed a detailed tissue section analysis in six animals. After the open chest

250 epicardial mapping procedure, we excised the heart out of the chest and immersed in an ice-cold

251 cardioplegia solution containing (mmol/l) NaCl 128, $\mathrm{KCl}$ 15, HEPES 10, $\mathrm{MgSO}_{4} 1.2, \mathrm{NaH}_{2} \mathrm{PO}_{4}$ 0.6,

$252 \mathrm{CaCl}_{2}$ 1.0, glucose 10 , and heparin $(0.0001 \mathrm{U} / \mathrm{ml}) ; \mathrm{pH}$ 7.4. The solutions were equilibrated with

$253100 \% \mathrm{O}_{2}$. We then cannulated the heart via the aorta and perfused with ice-cold cardioplegia

254 solution containing protease inhibitors (Millipore Sigma, P8340) until the vessels were clear of

255 blood, and tissue was cold. The 6 mapped bi-atrial tissue regions in the size of the triangular

256 mapping catheter were dissected. Specimens from six dogs were fixed in $10 \%$ formalin and

257 embedded in paraffin for further examination.

259 Masson's trichrome staining

260 Paraffin sections with $5 \mu \mathrm{m}$ thickness were stained using Masson's Trichrome stain kit (Sigma).

261 Paraffin was then removed in Xylene for three minutes twice and then in the mixture of $100 \%$

262 Xylene and absolute Ethanol for three minutes twice. Sections were then rehydrated with 
medRxiv preprint doi: https://doi.org/10.1101/2020.12.14.20248171; this version posted December 16, 2020. The copyright holder for this preprint (which was not certified by peer review) is the author/funder, who has granted medRxiv a license to display the preprint in perpetuity. All rights reserved. No reuse allowed without permission.

263 ethanol series which include absolute Ethanol (twice), 95\% Ethanol, 70\% Ethanol, and 50\%

264 Ethanol. The paraffin sections were treated with Bouin's mordant at room temperature

265 overnight. The following day the sections were rinsed in running water to remove excess yellow.

266 The sections were stained in Weigert's Iron Hematoxylin solution for five minutes. Next, it was

267 washed under running water for five minutes and briefly rinsed in distilled water. The sections

268 were then stained in Beibrich Scarlet-Acid fuchsin for five minutes, followed by a rinse in distilled

269 water. Subsequently, the sections were incubated in the phosphomolybdic-phosphotungstic acid

270 solution for five minutes. The issue section was then stained in the Aniline Blue solution for five

271 minutes. The sections were incubated in $1 \%$ Glacial acetic acid for two minutes. The sections

272 were then dehydrated through ethanol series, which include $70 \%, 90 \%$, and absolute Ethanol

273 (twice). Then, the sections were placed in Xylene for five minutes twice. A coverslip was finally

274 placed using cytosol mounting media on the sections for microscope examination.

275

276 Examination of Uniformity of Fiber Orientation and Degree of Fibrosis -

277 Masson's trichrome stained tissue sections at different depths $(0,200$, and $500 \mu m)$ from the 278 epicardial surface were digitized with the NanoZoomer 2.0-HT (Hamamatsu Photonics.

279 Hamamatsu Japan) at 5x magnification. The whole sections were divided into quadrants by 280 drawing regions of interest for the quantitative morphometric analysis. We quantified uniformity 281 of fiber orientation in RAP atrial tissue sections at $200 \mu \mathrm{m}$ and $500 \mu \mathrm{m}$ from the epicardial surface 282 and quantified the orientation of the myocytes. The standard deviation of the detected fiber 283 angle and number of fiber crossing points were quantified in ROI's of $2.5 \mathrm{~mm} \times 2.5 \mathrm{~mm}$ similar to 284 the electrode sizes of the Unemap mapping plaque using the ImageJ plugin OrientationJ and fiber 
medRxiv preprint doi: https://doi.org/10.1101/2020.12.14.20248171; this version posted December 16, 2020. The copyright holder for this preprint (which was not certified by peer review) is the author/funder, who has granted medRxiv a license to display the preprint in perpetuity. All rights reserved. No reuse allowed without permission.

285

crossing were defined as angle > 30 degrees between neighbored ROI's (compare Supplemental Data S45-50). ${ }^{32}$ We further analyzed the degree of focal fibrosis in Masson's trichrome stained tissue section at $200 \mu \mathrm{m}$ levels with a semi-automatic color-based segmentation and the degree of interstitial fibrosis as there was qualitative similarity among sections at different depths using ImageJ and macro. ${ }^{32}$

\section{Clinical Mapping and Ablation Procedure -}

Nine early persistent AF Patients at Northwestern Memorial Hospital were included. The patients received conscious sedation or general anesthesia at the discretion of the treating physician. This study was approved by the institutional review board at Northwestern Memorial Hospital (Northwestern University). After obtaining access, transseptal puncture across the interatrial septum was performed using an SL1 (Abbott, Chicago, IL) or Preface sheath (Biosense Webster, New Brunswick, NJ) and Bayliss RF needle (NRG ${ }^{\circledR}$ Transseptal Needle, Baylis Medical). Intravenous heparin was given with an activated clotting time (ACT) goal of $>300$ s. 3D mapping was used at the discretion of the operator. Using the Advisor ${ }^{\circledR}$ HD Grid Mapping Catheter (Abbott) with 16 electrodes arranged in a $4 \times 4$ grid, EGMs were recorded and tagged according to the anatomic location (posterior wall, roof, lateral wall, septum) on the Ensite NavX mapping system ${ }^{\circledR}$ (Abbott). Electrograms were sampled at $2 \mathrm{kHz}$ and bipolar electrogram filtering 30 to $300 \mathrm{~Hz}$ with a $60 \mathrm{~Hz}$ noise filter. We detected slow conduction at reentry sites and focal sources near the pulmonary veins in nine patients using the high-definition (HD) mapping catheter (Figure 8A). Example bipolar voltage map and LAT map of the left atrium near the pulmonary veins are given in Figure $8 \mathrm{G}-\mathrm{H}$. 
Statistics

309 Continuous variables with normal distribution are reported as mean and SD. For those with non-

310 normal distribution, range and median values are reported. For comparisons of continuous

311 variables, a 2-sample t-test with unequal variance was used if data were normally distributed and

312 a Wilcoxon rank-sum test was used for non-normally distributed variables. For comparisons of

313 multiple variables, 1- or 2-way ANOVA methods were used. Correlation between continuous

314 variables (stability of rotational activities and electrogram measures) was evaluated using linear

315 regression. The normality assumption was tested using the skewness and kurtosis test. A P value

$316<0.05$ was considered statistically significant. Analyses were conducted using STATA SigmaPlot

31714.0 software (Systat Software, Inc., CA, USA) and MatLab.

319 Results

320 Baseline Characteristics in the Animals and Patients

32148 dogs and nine patients were studied. A total of $43 \mathrm{AF}$ and five sinus/ paced rhythm hound 322 dogs underwent electrophysiological study. During AF, multiple rotational activities of different 323 cycle lengths (103 $\pm 13 \mathrm{~ms}$, median $103 \mathrm{~ms})$ were present in both atria in all 18 hearts. The 324 rotational activity was detected in all regions (32 per heart, $5 \pm 2$ per region, median 4 ) with 325 stability over $424 \pm 505 \mathrm{~ms}$. (median $270 \mathrm{~ms}$, range $120-4940 \mathrm{~ms}$ ). The animal characteristics are 326 summarized in Table 1. 
medRxiv preprint doi: https://doi.org/10.1101/2020.12.14.20248171; this version posted December 16, 2020. The copyright holder for this preprint (which was not certified by peer review) is the author/funder, who has granted medRxiv a license to display the preprint in perpetuity. All rights reserved. No reuse allowed without permission.

Rotational activities were detected in all 6 bi-atrial regions. Figure 1B) is a representative example of AF showing multiple rotational activities of different CLs in all six atrial regions in the same heart (heart \#10). Rotational activities, likely AF drivers, were significantly faster in the PLA (94 \pm 7

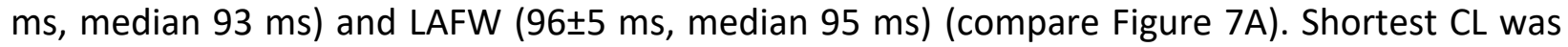

333 detected in the PLA in 47\%, in the LAFW in 33\%, in the PRA in 13\%, and in the RAA in $7 \%$ of all

334 animals (Figure 1D). In contrast, the longest CL was in the RAA in $90 \%$ and the RAFW in $10 \%$ of all

335 animals. Rotational activities were most stable in the RAA (405 $\pm 219 \mathrm{~ms}$, median $420 \mathrm{~ms}$ ) and 336 second in the posterior left atrium (PLA) (267 $\pm 115 \mathrm{~ms}$, median $300 \mathrm{~ms})$. The highest stability of 337 rotational activity was detected in the RAA in $80 \%$, in the RAFW and LAFW in $10 \%$ of the animals.

338 The second most stable reentries were detected in the LAA in $60 \%$ and the RAFW in $40 \%$ of all 339 animals. Importantly, rotational activity was most present in the RAA in $12 \%$ (average) of the 340 mapping time, second in the RAFW and third in the PLA of the mapping time (Figure 1C).

342 Redefining Trajectory and Anchoring of AF Drivers

343 Figure $2 \mathrm{~A}$ is a representative example of AF activation showing stable rotational activities in all 6 344 bi-atrial regions in the same animal (heart \#10). The rotational activities during AF anchored 345 frequently at slow conduction zones (number $n>=3$ ) of activation delay (14.9 \pm 5.2 ms, median $34613.0 \mathrm{~ms}$, range $10-35 \mathrm{~ms}$ ) over a distance of $2.5 \mathrm{~mm}$ (Figure 2B, and Supplemental Data Figure 347 S24-S25). In contrast-to the phase singularity analysis of reentry in previous reports, we defined 348 the trajectory and anchoring of rotational activities based on activation and activation delay in 349 high-resolution mapping data. Figure 2D (left panel) shows an oval shape schematic of a 350 reentrant circuit trajectory, which is typically described in the literature. In contrast, high-density 
medRxiv preprint doi: https://doi.org/10.1101/2020.12.14.20248171; this version posted December 16, 2020. The copyright holder for this preprint (which was not certified by peer review) is the author/funder, who has granted medRxiv a license to display the preprint in perpetuity. All rights reserved. No reuse allowed without permission.

351 mapping shows that the trajectory of reentry based on earliest and latest activation was different

352 with patterns of lines with normal conduction (Figure 2E) and slow conduction at the edges of

353 these line patterns. Figure 2D (right panel) exemplarily shows the schematic of the new reentry

354 model in form of a polygon with observed curvature angle $\left(138^{\circ}\right)$ between these propagation

355 lines. Activation delay at the edges of the reentrant trajectory ( $15 \pm 5 \mathrm{~ms}$, median $13 \mathrm{~ms}$ ) was four

356 times slower compared to the straight and fast conduction at propagation lines with activation

357 delay (4.1 $\pm 2.0 \mathrm{~ms}$, median $4.0 \mathrm{~ms}$ ) (Figure $2 \mathrm{C})$. These detected slow and highly curved conduction

358 regions measured $>2.5 \mathrm{~mm} \times 2.5 \mathrm{~mm}$ and were stable over time. Both trajectories of earliest and

359 latest activation within activation time maps over time had the same overlapping slow

360 conduction regions (Figure $2 \mathrm{~B}$, left and right panel). As described in the literature, slow

361 conduction zones are located at abrupt changes in the fiber direction, compare schematic in

362 Figure 2 F.) Using this newly developed method based on the earliest and latest activation, the

363 accuracy of automatically detecting reentries increased by about $30 \%$ compared to previously

364 described methods, which used Hilbert phase maps.

365

366 Episodes in the Development of Stable Reentry and Slow Conduction Characteristics

367 The activation patterns necessary for the induction of a stable reentry based on high-resolution

368 mapping remained unclear. Supplemental Data Figure S27 (all times) and Figure 3A) (parts) show

369 a representative example of the development stages of rotational activity over time consisting of

370 varying activation pattern episodes (heart \#7,region RAA): The first episode is a repetitive planar

371 wave activation (0-570ms). Then a time episode of repetitive focal wave activation (600-1830ms)

372 continues, which importantly induces a first instable reentrant loop (1860-1890ms). Importantly 
medRxiv preprint doi: https://doi.org/10.1101/2020.12.14.20248171; this version posted December 16, 2020. The copyright holder for this preprint (which was not certified by peer review) is the author/funder, who has granted medRxiv a license to display the preprint in perpetuity. All rights reserved. No reuse allowed without permission.

373 this reentrant loop resulted in chaotic activations over $210 \mathrm{~ms}$ with multiple small slow

374 conduction zones (Figure 3A, time 1920-2010ms), which then induced stable rotational activity

375 (2070-4470ms). The activation time maps, trajectory, and activation delay of earliest and latest

376 activation in 2 reentrant loops of this stable reentry are shown in Figure 3B. We further assessed

377 to characterize these slow conduction regions which are responsible for the anchoring of

378 reentrant drivers. Figure 3 C) exemplarily shows the activation delay over time in eight following

379 reentrant loops (heart \#7 in the RAA). Importantly activation delays in reentrant loops were

380 similar over time in all bi-atrial regions (Figure 3D).

382 Termination of Stable Reentry and Overlapping Slow Conduction Regions during Reentry and

383 Planar Wave Activity

384 Episodes of stable reentries were frequently observed over time. However, the reason for the 385 abrupt ending of reentries in high-resolution mapping remained unclear. We, therefore, analyzed

386 the $\mathrm{CL}$ variations during and before the termination of stable reentry. We found that in stable 387 reentries spontaneous increases in $\mathrm{CL}$ occurred before the termination of the rotations. Figure $3884 \mathrm{~A}$ ) shows an example of a stable reentry (2 seconds). After the increase in CL from $120 \mathrm{~ms}$ to $389150 \mathrm{~ms}$, the reentry terminated then resulted in aplanar wave activation. Activation patterns in 390 AF are complex. In this study, episodes of different activation patterns including rotational, focal 391 activity, complex activation pattern, and normal nearly planar wave activations varied over time 392 in the same region. Figure 4B shows a representative example of the RAA (heart \#10) of varying 393 episodes of rotational activity, and episodes of more organized nearly planar wave activation 394 (Figure 4B) in the same region. Importantly, the zones of slow conduction during the reentrant 
medRxiv preprint doi: https://doi.org/10.1101/2020.12.14.20248171; this version posted December 16, 2020. The copyright holder for this preprint (which was not certified by peer review) is the author/funder, who has granted medRxiv a license to display the preprint in perpetuity. All rights reserved. No reuse allowed without permission. episodes in LAT maps. Also, focal activities between the lines of block were frequently observed

414 at the same locations (Figure $5 \mathrm{~B}-\mathrm{C}$ ). Figure $5 \mathrm{C}$ demonstrates a figure-of-eight activation along 415 thin activation lines in the PRA (heart \#5) frequently observed at the same location with the activity were at the same locations also present during planar wave activation (marked in black in Figure 4B) and during sinus rhythm (marked in black in Figure 4C). Figure 4B) exemplarily shows a selected bipolar EGM from the rotational activation episode (Figure 4B, upper right panel) and the more organized activation episode (Figure 4B, lower right panel). Activation delay increased by the factor 3-4 during AF compared to sinus rhythm or planar wave activation. Regional cycle length variation shown as the standard deviation of $\mathrm{CL}$ was higher in the right atrium compared to the left atrium (Figure 4D). Conduction delay zones were a cycle length dependent phenomenon. Activation delay decreased significantly with increasing $\mathrm{CL}$, during $\mathrm{AF}$ and SR/paced rhythm with pacing intervals (200ms to $500 \mathrm{~ms}$ ) (Figure $4 \mathrm{E}$ ).

\section{Thin Line Activation, Line of Block, Figure-of-Eight Activation -}

The activation patterns focal activity, epicardial breakthrough, and line of block were reported in previous studies in high-density epicardial AF mapping. ${ }^{33}$ In this study, we further found a new activation pattern 'thin line activation', (Figure 5A). We defined 'thin line activation' as simultaneous earliest activation (red in activation time maps) along thin line regions on the epicardial surface. Importantly these thin line activations often closely juxtaposed to activation patterns such as focal activity and lines of block (Figure 5B). Figure 5B shows focal activity as simultaneous activation between lines of block, the locations, which were consistent over time dimension of the figure-of-eight reentrant trajectory of $7.5 \mathrm{~mm} \times 15 \mathrm{~mm}$. Importantly most figure- 
medRxiv preprint doi: https://doi.org/10.1101/2020.12.14.20248171; this version posted December 16, 2020. The copyright holder for this preprint (which was not certified by peer review) is the author/funder, who has granted medRxiv a license to display the preprint in perpetuity. All rights reserved. No reuse allowed without permission.

417 of-eight-activations with small circuit dimensions were located in the PLA. Further, the detected

418 focal source dimensions measured with the length and width of the simultaneous earliest

419 activations in $5 \mathrm{~ms}$ isochrones and the number of focal sources per AF cycle are given in Figure

420 5D. The detected lengths and widths of the simultaneous activations were $(4.9 \pm 5.0 \mathrm{~mm}$, and

$4214.9 \pm 6.2 \mathrm{~mm})$, but the range of dimensions between 1-30 $\mathrm{mm}$ also led to thin line activations

422 (Figure 5 B-C).

423

\section{Correlation of Fiber Crossings with Stability of Reentry -}

425 We further analyzed the underlying substrate characteristics in all bi-atrial regions in six animals

426 (Figure 6). Figure 6A shows the exemplary tissue sections in all regions in heart \#7. The highest

427 degree of foal fibrosis/ fat was detected in the PLA (49 $\pm 14 \%$, median $42 \%)$ and in the LAFW

428 (47士19\%, median 50\%) (Figure 6B). There was no significant regional difference in fiber

429 anisotropy detected as the standard deviation of fiber orientation (measured in degree) (Figure

430 6C). But the fiber crossings density was significantly higher in the PLA, LAA, and in the right atrium

431 in the RAA (Figure 6). However, there was no significant correlation between fiber orientation

432 and stability of rotational activity. In contrast, the stability of rotational activity correlated with

433 the number of fiber crossings per tissue section ( $\mathrm{R}=0.6, \mathrm{P}<0.05)$ (Figure $6 \mathrm{E})$. Furthermore, the

434 slow conduction regions were located at fibrotic/ fat tissue regions in histological tissue sections

$435(>=3 \mathrm{~mm})$ and low voltage regions ( $<1 \mathrm{mV})$ (Supplemental Data Figure S23). Slow conduction may

436 be the product of increased fiber crossings as well as more fibrosis/fat. Interestingly nearly no

437 dense fibrosis/ fat zones were detected in the appendages, but about 1.5 fibrosis/ fat regions per

438 tissue section were detected in the remaining bi-atrial regions (Figure 6F). Importantly, more 
medRxiv preprint doi: https://doi.org/10.1101/2020.12.14.20248171; this version posted December 16, 2020. The copyright holder for this preprint (which was not certified by peer review) is the author/funder, who has granted medRxiv a license to display the preprint in perpetuity. All rights reserved. No reuse allowed without permission.

439 than $90 \%$ of the detected fibrosis and fat regions were located near fiber crossings in the atrial

440 regions (Figure 6G).

441

442 Correlation of Rotational Activity Stability with Electrogram Measures -

443 We further correlated different established electrogram measures with the detected stability of

444 rotational activity in this study. Importantly, stability of rotational activity correlated with

445 electrogram measures $\mathrm{OI}(\mathrm{R}=0.68), \mathrm{FI}(\mathrm{R}=0.61)$, ShEn ( $\mathrm{R}=0.58)$ and $\mathrm{CL}(\mathrm{R}=0.56)$, but not with $\mathrm{DF}$

446 ( $R=0.28),(p<0.0001$, for all comparisons) (Supplemental Data Figure S52). The stability of

447 rotational activity correlated best with the electrogram measure OI.

449 PVI Reduced AF Drivers in Remote Regions to the PVs -

450 Pulmonary vein isolation is thought to be efficacious in patients with paroxysmal and persistent

451 atrial fibrillation. However, the underlying mechanisms by which PVI leads to beneficial atrial

452 remodeling are not clear. We hypothesized that PVI affects rotational activity and slow

453 conduction zones in regions close to and remote to the PVs. We further hypothesized that a

454 partial mechanism may be CL prolonguation, which improves conduction (i.e. decreases slow

455 conduction zones) and therefore decreases the stability of anchored rotational activity. To assess

456 the beneficial effects of PVI on AF, we performed epicardial pulmonary vein isolation in five

457 hearts. PVI led to a significant increase in cycle length (range: $2.3 \%-14.1 \%$ ) (Figure $7 \mathrm{~A}$ ) and

458 decreased stability of rotational activities in nearly all atrial regions remote from the site of

459 ablation (Figure 7B). Slow conduction zones were similarly located pre and post PVI

460 (Supplemental Data Figure S53). Importantly the percentage change of slow conduction zones 
medRxiv preprint doi: https://doi.org/10.1101/2020.12.14.20248171; this version posted December 16, 2020. The copyright holder for this preprint (which was not certified by peer review) is the author/funder, who has granted medRxiv a license to display the preprint in perpetuity. All rights reserved. No reuse allowed without permission.

461 pre vs post-PVI was highest in the right atrial appendage (50\% reduced slow conduction zones)

462 (Figure 7C) and correlated with the stability of rotational activity at baseline (Figure 7D). PVI 463 decreased rotational driver stability throughout the atria, by affecting the extent of conduction

464 slowing at 'slow conduction' zones also in remote regions to the PVs. The extend of slow 465 conduction further correlated with the fiber crossing density in the histological tissue analysis 466 (Figure 7E).

468 Patient Characteristics and Evaluation of AF Drivers and Slow Conduction in Patients -

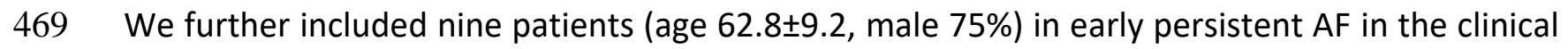
470 study. The majority of the patients had bi-atrial dilatation (75\%) with a mean left atrium volume 471 of $67.1 \pm 45.9$ body surface area. The mean AF cycle length was $146 \pm 3 \mathrm{~ms}$ (median 134.2). The 472 clinical patient characteristics of the study population are summarized in Table 2 . We evaluated

473 slow conduction at reentry sites and at focal sources near the pulmonary veins in 9 patients using

474 the high-definition (HD) mapping catheter with 16 equidistant electrodes (HD Grid Mapping 475 Catheter Sensor Enabled, Abbott Technologies, Minneapolis, MN) (Figure 8A). Similar to the 476 findings observed in the rapid atrial pacing model in animals, rotational activity trajectories had 477 maximal activation delay zones at the edges of the reentrant circuits. The activation time map of 4781 AF cycle in the PLA (Figure 8B) shows a reentrant circuit with the 2 to 6 fold higher activation 479 delay at one edge of the reentrant trajectory compared to the other reentry trajectory segment 480 parts. Figure 8 C) exemplarily shows an activation time map during CS-pacing. We detected $4812.3 \pm 1.6$ (median 2) reentries and $2.1 \pm 1.1$ (median 2 ) focal sources per AF cycle in patients in the 482 left atrium (Figure 8D). Activation delay and maximal activation delay at focal sources were 
medRxiv preprint doi: https://doi.org/10.1101/2020.12.14.20248171; this version posted December 16, 2020. The copyright holder for this preprint (which was not certified by peer review) is the author/funder, who has granted medRxiv a license to display the preprint in perpetuity. All rights reserved. No reuse allowed without permission.

$48320.2 \pm 19.1 \mathrm{~ms}$ (median $15.7 \mathrm{~ms}$ ) and 26.8 $\pm 17.4 \mathrm{~ms}$ (median $24.4 \mathrm{~ms}$ ). Activation delay and

484 maximal activation delay at reentries were $9.3 \pm 8.8 \mathrm{~ms}$ (median $9.2 \mathrm{~ms}$ ) and $20.2 \pm 8.1 \mathrm{~ms}$ (median

$48519.6 \mathrm{~ms}$ ) along $2.5 \mathrm{~mm}$ (Figure 8E). The activation delay was $2 \mathrm{x}$ higher in AF compared to SR/ CS-

486 pacing patient maps (Figure 8F). Figure 8G presents an exemplarely bipolar voltage map and the

487 corresponding activation time map in the Ensite NavX mapping system ${ }^{\circledR}$ (Abbott) (Figure $8 \mathrm{H}$ ).

\section{Discussion}

Are Reentries Frequently Anchored between Slow Conduction Zones in All Bi-Atrial Regions? -

491 A detailed analysis of rotational activities in both atria, including the appendages based on high-

492 resolution contact mapping, has not been systematically performed in prior studies. In the

493 current study, our results demonstrate that potential AF drivers were likely the result of

494 activation wavefronts emanating from interacting rotational and focal activity in all 6 analyzed

495 bi-atrial regions. The rotational activity, automatically detected with a novel algorithm based on

496 the earliest and latest activation, was most stable in the appendages and PLA and anchored

497 between small slow conduction zones with activation delay > 10ms. In this work, we also

498 observed changing beat-to-beat wavefronts and varying spatiotemporal behavior of driver

499 activities. Reentrant activation was not sustained (median, 2.6 rotations lasting $449 \pm 89 \mathrm{~ms}$ ),

500 meandered, and recurred repetitively in the same region between $(n>=3)$ small slow conduction

501 zones.

502 Several previous studies showed PV-triggers and that AF triggers outside the PVs were located in

503 the vena cavae, the crista terminalis, the coronary sinus, the ligament of Marshall, the inter-atrial 504 septum, and the appendages. ${ }^{34-42}$ The role of the PVs in the development and maintenance of AF 
medRxiv preprint doi: https://doi.org/10.1101/2020.12.14.20248171; this version posted December 16, 2020. The copyright holder for this preprint (which was not certified by peer review) is the author/funder, who has granted medRxiv a license to display the preprint in perpetuity. All rights reserved. No reuse allowed without permission.

was published by Haïssaguerre et al.. Narayan et al, detected focal and rotor activity with spatial stability using low-resolution endocardial basket catheter and phase singularity AF mapping. ${ }^{16}$ Recently, Rudy et al, identified in a noninvasive mapping study in paroxysmal and persistent AF patients multiple (2-5) concurrent wavelets (92\%), with both simultaneous focal activation from areas near the pulmonary veins (69\%) and non-pulmonary veins (62\%), but reentry which sustained $>1$ rotation was rarely seen. ${ }^{14}$ In contrast, Haissaguerre et al showed AF drivers in a

511 noninvasive mapping study with $80.5 \%$ reentries and $19.5 \%$ focal breakthroughs with incessantly

512 changing beat-to-beat wavefronts and spatiotemporal behavior. ${ }^{43}$ de Groot et al. showed in high-

513 density sequential epicardial mapping in patients with AF epicardial breakthrough sites some

514 intermittent focal activity $(0.8 \%) \cdot{ }^{33}$ Recently, Kalman et al., showed, using sequential, epicardial

515 LA and RA mapping in patients with persistent AF, intermittent foci ( $\leq 2$ beats), and intermittent

516 reentry ( $\geq 2$ rotations), but neither sustained focal nor sustained reentrant activation was

517 detected. ${ }^{18}$ However, in this study, we found the most stable rotational activities pre and post

518 PVI in the RAA and also in the LAA in which AF drivers were more stable compared to most other

519 regions. Based on the findings in this work, electrical isolation of the appendages in addition to

520 PVI may further improve the success rate of freedom from AF compared to PVI only. A previous

521 clinical study showed that the left atrial appendage may be an underrecognized trigger site of

522 atrial fibrillation. ${ }^{44}$ Furthermore, Natale and colleagues showed that empirical electrical isolation

523 of the left atrial appendage improved long-term freedom from atrial arrhythmias. ${ }^{45} \mathrm{In}$ a

524 comparison of our study to previous reports, the finding of rotational driver activation during AF

525 is consistent, in whole or in part, with the findings of others. 7, 8, 10,11, 18, 33 However, importantly,

526 our data further characterized AF drivers with slow conduction regions in bi-atrial regions. 
medRxiv preprint doi: https://doi.org/10.1101/2020.12.14.20248171; this version posted December 16, 2020. The copyright holder for this preprint (which was not certified by peer review) is the author/funder, who has granted medRxiv a license to display the preprint in perpetuity.

529 Crossings -

530 Almost 100 years ago, Garrey and Lewis first hypothesized that re-entry could sustain and drive

531 AF. ${ }^{46}$ Allessie et al. published in 1973, that reentry may be functional and not require an

532 anatomically defined pathway. ${ }^{47}$ In this work, we demonstrated that the reentrant circuit

533 trajectories were more complex than circles or ovals like those previously described and followed

534 line patterns with a curvature angle between lines, which appeared to be at last partially

535 anchored to myofiber crossings or regions of fibrofatty infiltrations. The velocity of stable

536 rotational activities along the described line patterns with curvature propagation angle was $4 \mathrm{x}$

537 slower at the edges of the trajectory compared to the propagation lines. These slow conduction

538 zones appeared to be located largely over crossing fibers, fibrosis, or fat tissue zones in the

539 histological tissue section analysis. This finding indicates that regions of fibrofatty infiltrations

540 may at least partially develop at fiber crossings, with the densest fibrofatty infiltrations in the PLA

541 near the pulmonary veins and in the LAFW. Furthermore, the stability of rotational activity

542 correlated with the number of fiber crossings. Several previous studies suggest that fiber

543 orientation distribution is an important factor in the development of AF. However, in this study,

544 we detected only a trend between fiber orientation distributions measured with the standard

545 deviation of fiber orientations and stability of rotational activity. In contrast to previous studies,

546 we analyzed for the first time also the number of fiber crossings per tissue section in different bi-

547 atrial regions. Importantly, the number of fiber crossings were more specific and correlated with

548 the stability of rotational activity. 
medRxiv preprint doi: https://doi.org/10.1101/2020.12.14.20248171; this version posted December 16, 2020. The copyright holder for this preprint (which was not certified by peer review) is the author/funder, who has granted medRxiv a license to display the preprint in perpetuity. All rights reserved. No reuse allowed without permission.

549 Previous studies demonstrated that the main contributors to conduction and slow conduction in

550 the heat are: a) fiber orientation, b) Na channel characteristics, c) gap junction characteristics,

551 and d) the presence of fibrosis. Spach et al, demonstrated that conduction delay occurs at zones

552 that reveal sudden changes in the fiber direction. ${ }^{48}$ These sites also have an abrupt increase in

553 axial resistivity in the direction of propagation ensued, which may result in a decrease of the

554 safety factor for propagation. Hocini et al., 2002 further demonstrated that zones of activation

555 delay of up to $120 \mathrm{~ms}$ over distances as small as $3 \mathrm{~mm}$ in canine pulmonary veins correlated with

556 abrupt changes in fascicle orientation. ${ }^{49}$ The architecture of muscular sleeves in the PVs may

557 facilitate reentry and arrhythmias associated with the ectopic activity. In this RAP animal model,

558 activation delays, within $2.5 \mathrm{~mm} \times 2.5 \mathrm{~mm}$ was $>4$ times larger compared to normal activation

559 and activation frequently curved around slow conduction zones, which predisposed to reentry.

560 In patients, reentries and focal sources anchored at zones of activation delay up to 90 ms within

$5612.5 \mathrm{~mm}$ using the HD grid catheter near the PVs. Also in the clinical data, activation delay at the

562 reentrant trajectory was about $2 x$ higher at edges of the trajectory and 1.4 higher during AF

563 compared to SR/ CS-pacing similar to the animal data in this work. Furthermore, these findings

564 are in line with observations from Hanse and colleagues, who showed that stable reentries

565 anchored at regions of increased fiber angle (epicardial 37 degrees) and interstitial fibrosis (12.8

$566 \pm 1 \%)$ and made repetitive a U-turn at micro-anatomic tracks $(2 \mathrm{~mm}) .{ }^{50}$ However based on optical

567 mapping restrictions their human data study of AF drivers was limited to the lateral right atrium.

568 Our findings of slow conduction sizes and activation delays are similar to observations from Spach

569 et al. 1982, Hocini et al., 2002 and Hanse et al. $2015^{48-50}$ Furthermore, we found in this work, 
medRxiv preprint doi: https://doi.org/10.1101/2020.12.14.20248171; this version posted December 16, 2020. The copyright holder for this preprint (which was not certified by peer review) is the author/funder, who has granted medRxiv a license to display the preprint in perpetuity. All rights reserved. No reuse allowed without permission.

570 slow conduction regions and anchored reentries around these slow conduction regions in all 6

571 analyzed bi-atrial regions.

572

573 The reentry models described in the literature in the last decades like circus movement, leading

574 circle, spiral wave, and the new proposed model of reentry along line patterns in the form of a

575 polygon are given in Figure 9A. In the circus movement reentry model, the anatomic reentry is

576 around a fixed obstacle and allows for an excitable gap. In the leading circle reentry model, the

577 conduction velocity (CV) and refractory period (RP) determine the circuit size. Also, the center of

578 the circuit is maintained refractory by centripetal wavelets. The spiral wave model describes a

579 curved wavefront with a core the so-called phase singularity (PS) which rotates around an

580 excitable but unexcited core. In contrast to the previous models, the new model describes both

581 structural and functional characteristics with slow conduction zones at the edges of propagation

582 line patterns. Previous models focused on the tip of the rotational activity analyzing the core with

583 phase singularity points in phase maps. ${ }^{20}$ In contrast, the focus in the new model is the earliest

584 and latest activation over time and slow conduction determined with activation delay within

585 activation time maps. The main findings of this study are given in summary in Figure 9B. Small

586 conduction zones $(>3 \mathrm{~mm})$ may be at least partially myofiber crossings or regions of fibrofatty

587 infiltrations in all bi-atrial regions. At these fiber crossings zones, focal fibrosis and fat tissue were

588 detected and may develop over time at these zones. These fiber crossing zones were frequency-

589 dependent zones of activation delay and rotational activity frequently anchored between these

590 small slow conduction zones. These zones were further located at the same locations in different

591 rhythms or activation patterns (AF and sinus rhythm, rotational activity, and planar wave 
medRxiv preprint doi: https://doi.org/10.1101/2020.12.14.20248171; this version posted December 16, 2020. The copyright holder for this preprint (which was not certified by peer review) is the author/funder, who has granted medRxiv a license to display the preprint in perpetuity. All rights reserved. No reuse allowed without permission.

592 activation). Importantly, activation delay increased at these small conduction zones during

593 rotational activity and decreased during planar wave activation or sinus rhythm. PVI increased CL

594 and reduced the activation delay and stability of rotational activity in nearly all regions remote

595 to the PVs. These activation delay zones at rotational activities were present in the animal model

596 and patients. Importantly, these findings result in a proposed new model of reentry. In contrast

597 to the previous models, the new model describes both structural and functional characteristics

598 with slow conduction zones at the edges of propagation line patterns. In contrast to previous

599 reports, this study provides a detailed mapping of all subregions in both atria, and a new slow

600 conduction model of reentry. Furthermore, this work demonstrates a clear dependence of slow

601 conduction on cycle length (both structural and functional), new human data, using HD grid, that

602 shows parallels between animal and clinical activation maps/reentry/focal activity and the effect

603 of PVI on rotational activity/conduction characteristics 'at a distance' to the PVs.

604

605 Implications

606 Our data describe a new paradigm for the mechanism that induces and maintains persistent AF.

607 Understanding the mechanism of reentry between small slow conduction regions presents

608 opportunities for new potential approaches to the treatment of persistent AF, especially for

609 ablation. In previous reports, the trajectory of reentries was calculated based on phase

610 singularities. ${ }^{20,28,29}$ But, this method is limited in robust reentrant detection and can falsely

611 detect phase singularities in the absence of rotors. ${ }^{30}$ In contrast, this work presents a completely

612 new method for detecting the trajectory of rotational activity more robustly (30\% more accurate)

613 based on earliest, latest activation, and activation delay. This new method may be integrated into 
medRxiv preprint doi: https://doi.org/10.1101/2020.12.14.20248171; this version posted December 16, 2020. The copyright holder for this preprint (which was not certified by peer review) is the author/funder, who has granted medRxiv a license to display the preprint in perpetuity. All rights reserved. No reuse allowed without permission.

614 future clinical systems to provide physicians a robust detection of AF drivers in addition to clinical

615 relevant slow conduction regions. Current success rates in persistent AF have been far from

616 optimal, and actual treatment approaches remain largely empirical because we have not

617 understood well enough the mechanism(s) maintaining persistent AF. The study of the

618 mechanism(s) maintaining AF has been limited by low resolution, and the difficulty in mapping

619 this complex arrhythmia. The data from this work may provide opportunities for a targeted,

620 rather than an empirical approach to treat AF.

\section{Study Limitations}

622 The findings cannot be assumed to apply to paroxysmal AF because our mapping study was only

623 performed in hearts with persistent AF. In this study, we focused on rotational activities. Further

624 studies of focal sources and breakthrough activities and subepicardial reentrant circuits need to

625 be performed. To prove that drivers maintain AF, first putative drivers need to be identified, and

626 then it needs to be demonstrated that AF reduced or stopped. However, we performed PVI only

627 in 5 hearts. Further studies with the performance of ablation at additional trigger sites and slow

628 conduction regions need to be performed. Although we detected similar characteristics of AF

629 drivers and slow conduction zones in patients and animals, the values based on animal studies

630 may not apply to the values in humans in all atrial regions. Also, the vulnerable substrate for AF

631 in humans develops over many years, leading to increased structural complexities, compared

632 with months in a dog model.

\section{CONCLUSION}


medRxiv preprint doi: https://doi.org/10.1101/2020.12.14.20248171; this version posted December 16, 2020. The copyright holder for this preprint (which was not certified by peer review) is the author/funder, who has granted medRxiv a license to display the preprint in perpetuity. All rights reserved. No reuse allowed without permission.

634 Rotational activities in all bi-atrial regions anchored between small frequency-dependent

635 activation delay zones in AF. PVI led to beneficial remodeling in bi-atrial regions remote to the

636 PVs. These data may identify a new paradigm for persistent AF.

637

638 Sources of Funding

639 This work was supported by grants from the American Heart Association and the National 640 Institute of Health, and a grant from Mr. and Mrs. Ronald and JoAnne Willens.

\section{Disclosures}

642 Provisional patent application 'Catheter system and method for the automatic detection of atrial 643 fibrillation sources', Rottmann et al., April. 19, 2020 
medRxiv preprint doi: https://doi.org/10.1101/2020.12.14.20248171; this version posted December 16, 2020. The copyright holder for this preprint (which was not certified by peer review) is the author/funder, who has granted medRxiv a license to display the preprint in perpetuity. All rights reserved. No reuse allowed without permission.

\section{Literature}

647 1. Moe GK and Abildskov JA. Atrial Fibrillation as a Self-Sustaining Arrhythmia 648 Independent of Focal Discharge. Circulation. 1957;16:917-917.

649 2. Allessie MA, Lammers WJ, Bonke IM and Hollen J. Intra-atrial reentry as a mechanism 650 for atrial flutter induced by acetylcholine and rapid pacing in the dog. Circulation. 1984;70:12365135.

652 3. Haissaguerre M, Jais P, Shah DC, Takahashi A, Hocini M, Quiniou G, Garrigue S, Le 653 Mouroux A, Le Metayer P and Clementy J. Spontaneous initiation of atrial fibrillation by ectopic 654 beats originating in the pulmonary veins. N Engl J Med. 1998;339:659-66.

655 4. Calkins H, Kuck KH, Cappato R, Brugada J, Camm AJ, Chen SA, Crijns HJG, Damiano 656 RJ, Davies DW, DiMarco J, Edgerton J, Ellenbogen K, Ezekowitz MD, Haines DE, Haissaguerre 657 M, Hindricks G, Iesaka Y, Jackman W, Jalife J, Jais P, Kalman J, Keane D, Kim YH, Kirchhof P, 658 Klein G, Kottkamp H, Kumagai K, Lindsay BD, Mansour M, Marchlinski FE, McCarthy PM, 659 Mont JL, Morady F, Nademanee K, Nakagawa H, Natale A, Nattel S, Packer DL, Pappone C, 660 Prystowsky E, Raviele A, Reddy V, Ruskin JN, Shemin RJ, Tsao HM and Wilber D. 2012 661 HRS/EHRA/ECAS Expert Consensus Statement on Catheter and Surgical Ablation of Atrial 662 Fibrillation: Recommendations for Patient Selection, Procedural Techniques, Patient Management 663 and Follow-up, Definitions, Endpoints, and Research Trial Design A report of the Heart Rhythm 664 Society (HRS) Task Force on Catheter and Surgical Ablation of Atrial Fibrillation. Developed in 665 partnership with the European Heart Rhythm Association (EHRA), a registered branch of the 666 European Society of Cardiology (ESC) and the European Cardiac Arrhythmia Society (ECAS); 667 and in collaboration with the American College of Cardiology (ACC), American Heart Association 668 (AHA), the Asia Pacific Heart Rhythm Society (APHRS), and the Society of Thoracic Surgeons (STS). Endorsed by the governing bodies of the American College of Cardiology Foundation, the American Heart Association, the European Cardiac Arrhythmia Society, the European Heart Rhythm Association, the Society of Thoracic Surgeons, the Asia Pacific Heart Rhythm Society, and the Heart Rhythm Society. Heart Rhythm. 2012;9:632-+.

5. Benharash P, Buch E, Frank P, Share M, Tung R, Shivkumar K and Mandapati R. Quantitative Analysis of Localized Sources Identified by Focal Impulse and Rotor Modulation Mapping in Atrial Fibrillation. Circ-Arrhythmia Elec. 2015;8:554-561.

676 6. Sueda T, Nagata H, Shikata H, Orihashi K, Morita S, Sueshiro M, Okada K and Matsuura 677 Y. Simple left atrial procedure for chronic atrial fibrillation associated with mitral valve disease. 678 Ann Thorac Surg. 1996;62:1796-1800.

679 7. Holm M, Johansson R, Brandt J, Luhrs C and Olsson SB. Epicardial right atrial free wall 680 mapping in chronic atrial fibrillation - Documentation of repetitive activation with a focal spread 681 - A hitherto unrecognised phenomenon in man. Eur Heart J. 1997;18:290-310.

682 8. Harada A, Konishi T, Fukata M, Higuchi K, Sugimoto T and Sasaki K. Intraoperative map 683 guided operation for atrial fibrillation due to mitral valve disease. Ann Thorac Surg. 2000;69:446684450.

6859 9u TJ, Doshi RN, Huang HLA, Blanche C, Kass RM, Trento A, Cheng W, Karagueuzian 686 HS, Peter CT and Chen PS. Simultaneous biatrial computerized mapping during permanent atrial 687 fibrillation in patients with organic heart disease. J Cardiovasc Electr. 2002;13:571-577. 
medRxiv preprint doi: https://doi.org/10.1101/2020.12.14.20248171; this version posted December 16, 2020. The copyright holder for this preprint (which was not certified by peer review) is the author/funder, who has granted medRxiv a license to display the preprint in perpetuity. All rights reserved. No reuse allowed without permission.

10. Yamauchi S, Ogasawara H, Saji Y, Bessho R, Miyagi Y and Fujii M. Efficacy of Intraoperative mapping to optimize the surgical ablation of atrial fibrillation in cardiac surgery. Ann Thorac Surg. 2002;74:450-457.

11. Nitta T, Ishii Y, Miyagi Y, Ohmori H, Sakamoto S and Tanaka S. Concurrent multiple left atrial focal activations with fibrillatory conduction and right atrial focal or reentrant activation as the mechanism in atrial fibrillation. J Thorac Cardiov Sur. 2004;127:770-778.

12. Sahadevan J, Ryu K, Peltz L, Khrestian CM, Stewart RW, Markowitz AH and Waldo AL. Epicardial mapping of chronic atrial fibrillation in patients - Preliminary observations. Circulation. 2004;110:3293-3299.

13. Sanders P, Berenfeld O, Hocini MZ, Jais P, Vaidyanathan R, Hsu LF, Garrigue S, Takahashi Y, Rotter M, Sacher F, Scavee C, Ploutz-Snyder R, Jalife J and Haissaguerre M. Spectral analysis identifies sites of high-frequency activity maintaining atrial fibrillation in humans. Circulation. 2005;112:789-797.

14. Cuculich PS, Wang Y, Lindsay BD, Faddis MN, Schuessler RB, Damiano RJ, Li L and Rudy Y. Noninvasive Characterization of Epicardial Activation in Humans With Diverse Atrial Fibrillation Patterns. Circulation. 2010;122:1364-+.

15. de Groot NMS, Houben RPM, Smeets JL, Boersma E, Schotten U, Schalij MJ, Crijns H and Allessie MA. Electropathological Substrate of Longstanding Persistent Atrial Fibrillation in Patients With Structural Heart Disease Epicardial Breakthrough. Circulation. 2010;122:16741682.

16. Narayan SM, Krummen DE, Clopton P, Shivkumar K and Miller JM. Direct or Coincidental Elimination of Stable Rotors or Focal Sources May Explain Successful Atrial Fibrillation Ablation On-Treatment Analysis of the CONFIRM Trial (Conventional Ablation for AF With or Without Focal Impulse and Rotor Modulation). J Am Coll Cardiol. 2013;62:138-147. 17. Haissaguerre M, Hocini M, Denis A, Shah AJ, Komatsu Y, Yamashita S, Daly M, Amraoui S, Zellerhoff S, Picat MQ, Quotb A, Jesel L, Lim H, Ploux S, Bordachar P, Attuel G, Meillet V, Ritter P, Derval N, Sacher F, Bernus O, Cochet H, Jais P and Dubois R. Driver Domains in Persistent Atrial Fibrillation. Circulation. 2014;130:530-538.

18. Lee G, Kumar S, Teh A, Madry A, Spence S, Larobina M, Goldblatt J, Brown R, Atkinson V, Moten S, Morton JB, Sanders P, Kistler PM and Kalman JM. Epicardial wave mapping in human long-lasting persistent atrial fibrillation: transient rotational circuits, complex wavefronts, and disorganized activity. Eur Heart J. 2014;35:86-97.

19. Swarup V, Baykaner T, Rostamian A, Daubert JP, Hummel J, Krummen DE, Trikha R, Miller JM, Tomassoni GF and Narayan SM. Stability of Rotors and Focal Sources for Human Atrial Fibrillation: Focal Impulse and Rotor Mapping (FIRM) of AF Sources and Fibrillatory Conduction. J Cardiovasc Electr. 2014;25:1284-1292.

20. Pandit SV and Jalife J. Rotors and the Dynamics of Cardiac Fibrillation. Circ Res. 2013;112:849-862.

21. de Bakker JM. Electrogram recording and analyzing techniques to optimize selection of target sites for ablation of cardiac arrhythmias. Pacing Clin Electrophysiol. 2019;42:1503-1516.

22. Berenfeld O. Quantifying activation frequency in atrial fibrillation to establish underlying mechanisms and ablation guidance. Heart Rhythm. 2007;4:1225-1234.

23. Jarman JW, Wong T, Francis DP, Davies DW, Kanagaratnam P, Markides V and Peters NS. Spatiotemporal Behaviour of High Dominant Frequency During Paroxysmal and Persistent Atrial Fibrillation in the Human Left Atrium. Circulation. 2009;120:S639-S639. 
medRxiv preprint doi: https://doi.org/10.1101/2020.12.14.20248171; this version posted December 16, 2020. The copyright holder for this preprint (which was not certified by peer review) is the author/funder, who has granted medRxiv a license to display the preprint in perpetuity. All rights reserved. No reuse allowed without permission.

24. Takahashi Y, Sanders P, Jais P, Hocini M, Dubois R, Rotter M, Rostock T, Nalliah CJ, Sacher F, Clementy J and Haissaguerre M. Organization of frequency spectra of atrial fibrillation: Relevance to radiofrequency catheter ablation. J Cardiovasc Electr. 2006;17:382-388.

25. Everett TH, Akar JG, Kok LC, Moorman JR and Haines DE. Use of global atrial fibrillation organization to optimize the success of burst pace termination. J Am Coll Cardiol. 2002;40:18311840.

26. Lo LW, Lin YJ, Tsao HM, Chang SL, Hu YF, Tsai WC, Tuan DC, Chang CJ, Lee PC, Tai CT, Tang WH, Suenari K, Huang SY, Higa S and Chen SA. Characteristics of Complex Fractionated Electrograms in Nonpulmonary Vein Ectopy Initiating Atrial Fibrillation/Atrial Tachycardia. J Cardiovasc Electr. 2009;20:1305-1312.

27. Ng J, Borodyanskiy AI, Chang ET, Villuendas R, Dibs S, Kadish AH and Goldberger JJ. Measuring the Complexity of Atrial Fibrillation Electrograms. J Cardiovasc Electr. 2010;21:649655.

28. Valderrabano M, Chen PS and Lin SF. Spatial distribution of phase singularities in ventricular fibrillation. Circulation. 2003;108:354-359.

29. Gray RA, Pertsov AM and Jalife J. Spatial and temporal organization during cardiac fibrillation. Nature. 1998;392:75-8.

30. Aronis KN, Berger RD and Ashikaga H. Rotors: How Do We Know When They Are Real? Circ Arrhythm Electrophysiol. 2017;10.

31. Kuklik P, Zeemering S, Maesen B, Maessen J, Crijns HJ, Verheule S, Ganesan AN and Schotten U. Reconstruction of instantaneous phase of unipolar atrial contact electrogram using a concept of sinusoidal recomposition and Hilbert transform. IEEE Trans Biomed Eng. 2015;62:296302.

32. Kennedy DJ, Vetteth S, Periyasamy SM, Kanj M, Fedorova L, Khouri S, Kahaleh MB, Xie Z, Malhotra D, Kolodkin NI, Lakatta EG, Fedorova OV, Bagrov AY and Shapiro JI. Central role for the cardiotonic steroid marinobufagenin in the pathogenesis of experimental uremic cardiomyopathy. Hypertension. 2006;47:488-95.

33. de Groot NM, Houben RP, Smeets JL, Boersma E, Schotten U, Schalij MJ, Crijns H and Allessie MA. Electropathological substrate of longstanding persistent atrial fibrillation in patients with structural heart disease: epicardial breakthrough. Circulation. 2010;122:1674-82.

34. Mansour M, Ruskin $J$ and Keane D. Initiation of atrial fibrillation by ectopic beats originating from the ostium of the inferior vena cava. J Cardiovasc Electr. 2002;13:1292-1295.

35. Lin WS, Tai CT, Hsieh MH, Tsai CF, Lin YK, Tsao HM, Huang JL, Yu WC, Yang SP, Ding YA, Chang MS and Chen SA. Catheter ablation of paroxysmal atrial fibrillation initiated by non-pulmonary vein ectopy. Circulation. 2003;107:3176-3183.

36. Shah D, Haissaguerre M, Jais $\mathrm{P}$ and Hocini M. Nonpulmonary vein foci: Do they exist? Pace. 2003;26:1631-1635.

37. Lee SH, Tai CT, Hsieh MH, Tsao HM, Lin YJ, Chang SL, Huang JL, Lee KT, Chen YJ, Cheng JJ and Chen SA. Predictors of non-pulmonary vein ectopic beats initiating paroxysmal atrial fibrillation - Implication for catheter ablation. J Am Coll Cardiol. 2005;46:1054-1059.

38. Yamada T, Murakami Y, Okada T and Murohara T. Focal atrial fibrillation associated with multiple breakout sites at the crista terminalis. Pace. 2006;29:207-210.

39. Pastor A, Nunez A, Magalhaes A, Awamleh P and Garcia-Cosio F. The superior vena cava as a site of ectopic foci in atrial fibrillation. Rev Esp Cardiol. 2007;60:68-71.

40. Hwang $\mathrm{C}$ and Chen PS. Ligament of Marshall: Why it is important for atrial fibrillation ablation. Heart Rhythm. 2009;6:S35-S40. 
medRxiv preprint doi: https://doi.org/10.1101/2020.12.14.20248171; this version posted December 16, 2020. The copyright holder for this preprint (which was not certified by peer review) is the author/funder, who has granted medRxiv a license to display the preprint in perpetuity. All rights reserved. No reuse allowed without permission.

41. Yamaguchi T, Tsuchiya T, Miyamoto K, Nagamoto Y and Takahashi N. Characterization of non-pulmonary vein foci with an EnSite array in patients with paroxysmal atrial fibrillation. Europace. 2010;12:1698-1706.

42. Elayi CS, Di Biase L, Bai R, Burkhardt JD, Mohanty P, Santangeli P, Sanchez J, Hongo R, Gallinghouse GJ, Horton R, Bailey S, Beheiry S and Natale A. Administration of Isoproterenol and Adenosine to Guide Supplemental Ablation After Pulmonary Vein Antrum Isolation. $J$ Cardiovasc Electr. 2013;24:1199-1206.

43. Haissaguerre M, Hocini M, Denis A, Shah AJ, Komatsu Y, Yamashita S, Daly M, Amraoui S, Zellerhoff S, Picat MQ, Quotb A, Jesel L, Lim H, Ploux S, Bordachar P, Attuel G, Meillet V, Ritter P, Derval N, Sacher F, Bernus O, Cochet H, Jais P and Dubois R. Driver domains in persistent atrial fibrillation. Circulation. 2014;130:530-8.

44. Di Biase L, Burkhardt JD, Mohanty P, Sanchez J, Mohanty S, Horton R, Gallinghouse GJ, Bailey SM, Zagrodzky JD, Santangeli P, Hao S, Hongo R, Beheiry S, Themistoclakis S, Bonso A, Rossillo A, Corrado A, Raviele A, Al-Ahmad A, Wang P, Cummings JE, Schweikert RA, Pelargonio G, Dello Russo A, Casella M, Santarelli P, Lewis WR and Natale A. Left atrial appendage: an underrecognized trigger site of atrial fibrillation. Circulation. 2010;122:109-18.

45. Di Biase L, Burkhardt JD, Mohanty P, Mohanty S, Sanchez JE, Trivedi C, Gunes M, Gokoglan Y, Gianni C, Horton RP, Themistoclakis S, Gallinghouse GJ, Bailey S, Zagrodzky JD, Hongo RH, Beheiry S, Santangeli P, Casella M, Dello Russo A, Al-Ahmad A, Hranitzky P, Lakkireddy D, Tondo C and Natale A. Left Atrial Appendage Isolation in Patients With Longstanding Persistent AF Undergoing Catheter Ablation: BELIEF Trial. J Am Coll Cardiol. 2016;68:1929-1940.

46. Lewis T, Drury AN and Iliescu CC. Further observations upon the state of rapid reexcitation of the auricles. Heart-J Stud Circ. 1921;8:311-339.

47. Allessie MA, Bonke FIM and Schopman FJ. Circus Movement in Rabbit Atrial Muscle as a Mechanism of Tachycardia. Circ Res. 1973;33:54-62.

48. Spach MS, Miller WT, Dolber PC, Kootsey JM, Sommer JR and Mosher CE. The Functional-Role of Structural Complexities in the Propagation of Depolarization in the Atrium of the Dog - Cardiac Conduction Disturbances Due to Discontinuities of Effective Axial Resistivity. Circ Res. 1982;50:175-191.

49. Hocini M, Ho SY, Kawara T, Linnenbank AC, Potse M, Shah D, Jais P, Janse MJ, Haissaguerre $\mathrm{M}$ and de Bakker JMT. Electrical conduction in canine pulmonary veins Electrophysiological and anatomic correlation. Circulation. 2002;105:2442-2448.

50. Hansen BJ, Zhao J, Csepe TA, Moore BT, Li N, Jayne LA, Kalyanasundaram A, Lim P, Bratasz A, Powell KA, Simonetti OP, Higgins RS, Kilic A, Mohler PJ, Janssen PM, Weiss R, Hummel JD and Fedorov VV. Atrial fibrillation driven by micro-anatomic intramural re-entry revealed by simultaneous sub-epicardial and sub-endocardial optical mapping in explanted human hearts. Eur Heart J. 2015;36:2390-401. 
medRxiv preprint doi: https://doi.org/10.1101/2020.12.14.20248171; this version posted December 16, 2020. The copyright holder for this preprint (which was not certified by peer review) is the author/funder, who has granted medRxiv a license to display the preprint in perpetuity. All rights reserved. No reuse allowed without permission.

824

825

826

827

828

829

830

831

832

833

834

835

836

837 
medRxiv preprint doi: https://doi.org/10.1101/2020.12.14.20248171; this version posted December 16, 2020. The copyright holder for this preprint (which was not certified by peer review) is the author/funder, who has granted medRxiv a license to display the preprint in perpetuity.

838 Table 1. Animal Characteristics

\begin{tabular}{|c|c|c|c|}
\hline \multicolumn{4}{|c|}{ Animal Characteristics } \\
\hline Animal & Gender & Weight & Pacing Days \\
\hline 1 & $\mathrm{~F}$ & 25 & 40 \\
\hline 2 & $\mathrm{~F}$ & 28 & 42 \\
\hline 3 & $\mathrm{~F}$ & 24 & 56 \\
\hline 4 & $\mathrm{~F}$ & 27 & 73 \\
\hline 5 & $\mathrm{~F}$ & 25 & 35 \\
\hline 7 & $\mathrm{~F}$ & 22 & 29 \\
\hline 8 & $\mathrm{~F}$ & 25 & 41 \\
\hline 9 & $\mathrm{~F}$ & 30 & 41 \\
\hline 10 & $\mathrm{~F}$ & 22 & 38 \\
\hline 11 & $\mathrm{~F}$ & 34 & 20 \\
\hline 12 & $\mathrm{~F}$ & 26 & 28 \\
\hline 13 & $\mathrm{~F}$ & 30 & 26 \\
\hline 14 & $\mathrm{~F}$ & 25 & 15 \\
\hline 15 & $\mathrm{~F}$ & 22 & 54 \\
\hline 16 & $\mathrm{~F}$ & 35 & 119 \\
\hline 17 & $\mathrm{~F}$ & 32 & 29 \\
\hline 18 & $F$ & 22 & 26 \\
\hline 19 & $\mathrm{~F}$ & 23 & 27 \\
\hline 21 & $\mathrm{M}$ & 29 & 55 \\
\hline 22 & $M$ & 33 & 53 \\
\hline 23 & $\mathrm{~F}$ & 31 & 54 \\
\hline 24 & $\mathrm{~F}$ & 32 & 28 \\
\hline 25 & $\mathrm{~F}$ & 25 & 98 \\
\hline 26 & $\mathrm{~F}$ & 22 & 34 \\
\hline 27 & $\mathrm{~F}$ & 18 & 55 \\
\hline 28 & $\mathrm{~F}$ & 27 & 40 \\
\hline 29 & $\mathrm{~F}$ & 30 & 49 \\
\hline 30 & $\mathrm{~F}$ & 20 & 40 \\
\hline 31 & $\mathrm{~F}$ & 29 & 41 \\
\hline 32 & $\mathrm{~F}$ & 23 & 35 \\
\hline 33 & $\mathrm{~F}$ & 27 & 41 \\
\hline 34 & $\mathrm{~F}$ & 22 & 61 \\
\hline 35 & M & 32 & 85 \\
\hline 36 & $\mathrm{~F}$ & 35 & 65 \\
\hline 37 & $\mathrm{~F}$ & 30 & 55 \\
\hline
\end{tabular}




\begin{tabular}{|l|l|l|l|}
\hline 38 & F & 34 & 98 \\
\hline 39 & F & 27 & 49 \\
\hline 40 & F & 24 & 42 \\
\hline 41 & F & 39 & 61 \\
\hline 42 & F & 32 & 49 \\
\hline 43 & M & 31 & 47 \\
\hline 44 & M & 26 & 72 \\
\hline 45 & M & 31 & 54 \\
\hline 46 & M & 34 & 56 \\
\hline 47 & M & 30 & 52 \\
\hline 48 & M & 32 & 85 \\
\hline
\end{tabular}

Gender: F, female, M, male.

\section{Table 2. Patient Characteristics}

\begin{tabular}{|l|c|}
\hline \multicolumn{2}{|l|}{ Patient Characteristics } \\
\hline Age (y) & $62.8 \pm 9.2$ \\
\hline Sex, male (\%) & 75 \\
\hline BMI & $30.2 \pm 2.6$ \\
\hline Diabetes mellitus (\%) & 0 \\
\hline Hypertension (\%) & 50 \\
\hline Type of AF (\%) \\
\hline Early persistent AF & 100 \\
\hline Long-standing persistent AF & 0 \\
\hline Permanent AF & 0 \\
\hline Duration of AF (months) & $1.5 \pm 2.4$ \\
\hline Time since first AF episode (years) & $17.0 \pm 12.8$ \\
\hline Prior ablation procedures (\%) & 26 \\
\hline Antiarrhythmic drugs/rate controlling agents $(\%)$ \\
\hline$\beta$-blockers & 50 \\
\hline Calcium channel blockers & 75 \\
\hline Digoxin & 25 \\
\hline Flecainide & 25 \\
\hline Amiodarone & 50 \\
\hline Underlying cardiac disease, $\mathrm{n}(\%)$ & 50 \\
\hline Coronary artery disease & \\
\hline Valvular disease & \\
\hline Mitral regurgitation & \\
\hline
\end{tabular}


medRxiv preprint doi: https://doi.org/10.1101/2020.12.14.20248171; this version posted December 16, 2020. The copyright holder for this preprint (which was not certified by peer review) is the author/funder, who has granted medRxiv a license to display the preprint in perpetuity.

All rights reserved. No reuse allowed without permission.

\begin{tabular}{|l|c|}
\hline Mitral stenosis & 25 \\
\hline Tricuspid regurgitation & 25 \\
\hline Echocardiogram \\
\hline Biatrial dilatation (\%) & 75 \\
\hline LA volume (mL/m $\left.{ }^{2}\right)$ & $67.1 \pm 45.9$ \\
\hline Impaired LV function (\%) & 50 \\
\hline LVEF 45\%-55\% & 25 \\
\hline LVEF 35\%-45\% & 25 \\
\hline
\end{tabular}

843 Data are shown as mean \pm SD for continuous variables, and \% for categorical variables. AF, 844 atrial fibrillation; BMI, body mass index; EF, ejection fraction; LA, left atrium; and LV, left 845 ventricle.

846

847

848 
medRxiv preprint doi: https://doi.org/10.1101/2020.12.14.20248171; this version posted December 16, 2020. The copyright holder for this preprint (which was not certified by peer review) is the author/funder, who has granted medRxiv a license to display the preprint in perpetuity.

849 Figures and Legends

850 Figure 1

A) Rotational Activities in all Regions

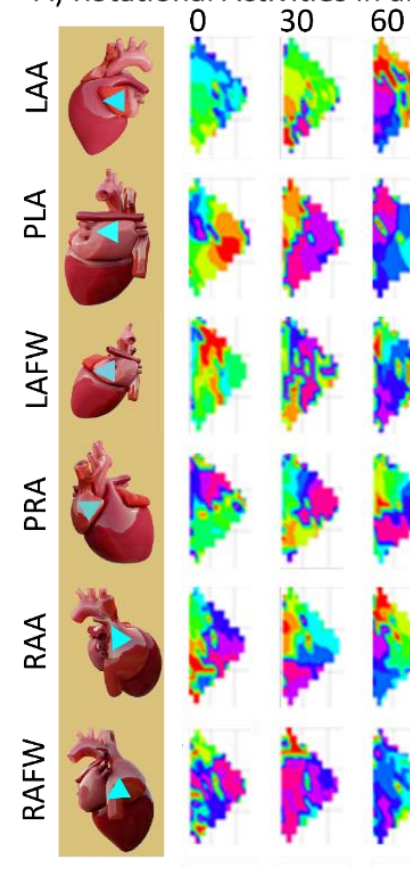

90120
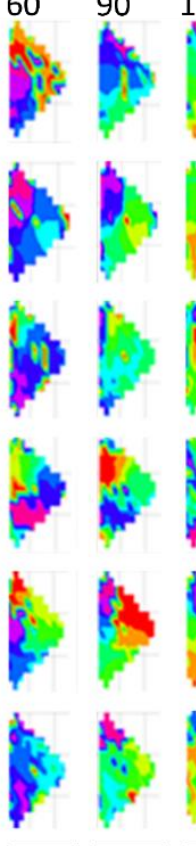

120
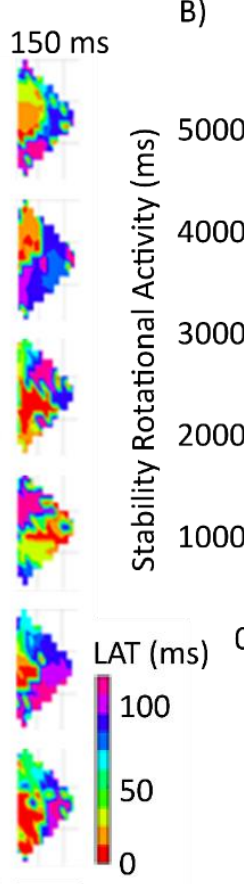

B)

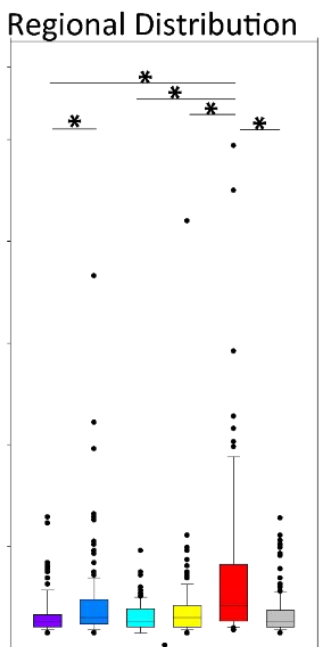

D) Smallest $\mathrm{CL}$ in Regions

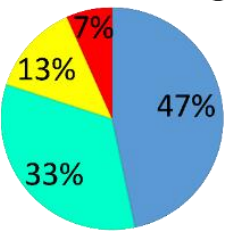

C)

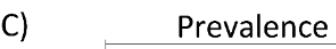

Figure1:

\section{Multiple}

rotational

activities

in

all regions

in both

atria.

853 A, (Left panel) Location of mapping plaque (blue triangle) in the 6 bi-atrial regions. (Right panel) Multiple 854 rotational activities in high-density local activation time (LAT) maps in all 6 atrial regions in heart \#10. B, The 855 highest stability of rotational activities was detected in the RAA and second in the PLA. C, Percentage of rotational activity time episodes vs total mapping time in all regions. The average rotational activity episodes covered $12 \%$ of the total mapping time in the RAA. D, Regional distribution of smallest CL of all regions in percentage of all hearts. ${ }^{*} P<0.05$ for all comparisons. 
medRxiv preprint doi: https://doi.org/10.1101/2020.12.14.20248171; this version posted December 16, 2020. The copyright holder for this preprint (which was not certified by peer review) is the author/funder, who has granted medRxiv a license to display the preprint in perpetuity.

A)
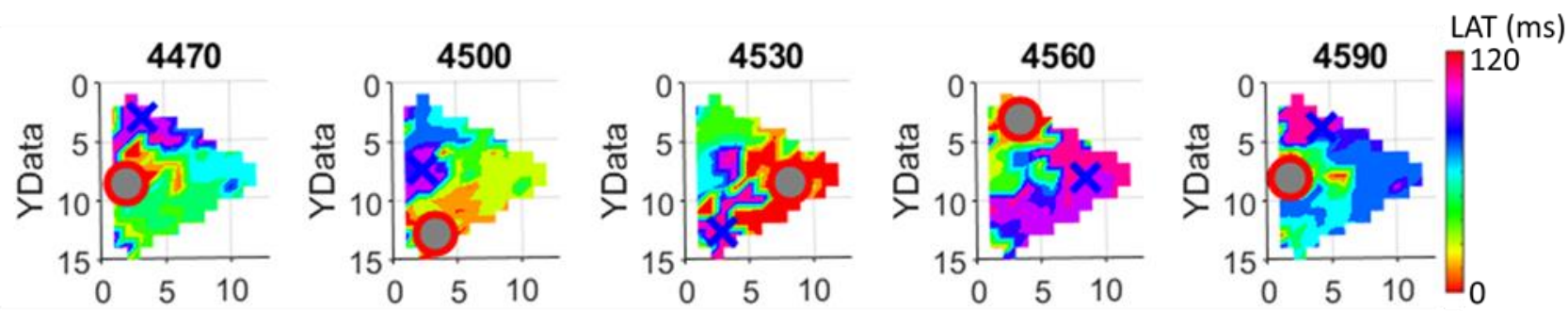

B) Reentrant circuit of 2 loops trajectory of earliest activation

Reentrant circuit of 2 loops in 5 msec steps

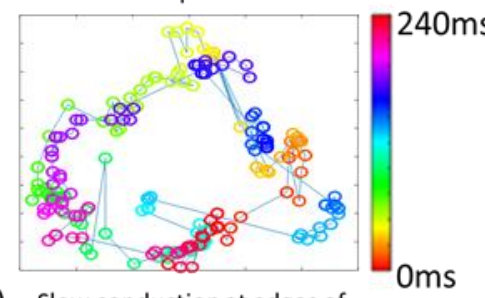

C) Slow conduction at edges of reentrant circuit in activation delay

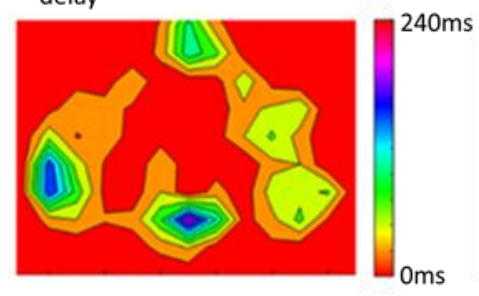
trajectory of latest activation in 5 msec steps

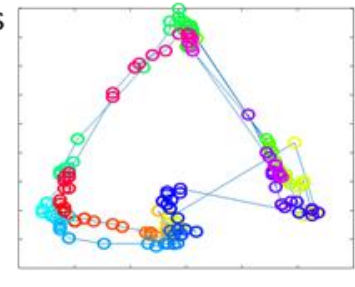

Slow conduction at edges of reentrant circuit in activation delay

D) Schematic of reentry in circular/ oval shape established in last

Redefined reentry circuit in polygon shape (line patterns) decades.

Focus on earliest \& latest $240 \mathrm{~ms}$

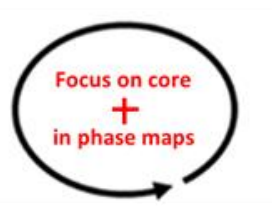
activation, activation delay in LAT maps

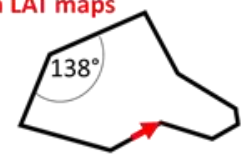

$\mathrm{ms}$

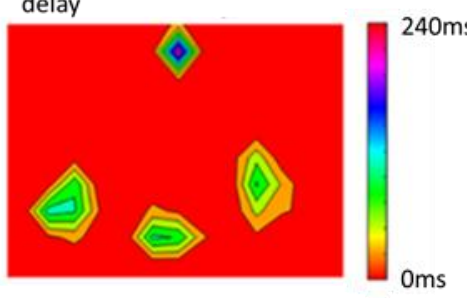

E) Fiber arrangement

* Abrupt change in fiber direction. Zones of activation delay.

Figure 2: Multiple interacting rotational activities in all regions in both atria.

$A$, Local activation time maps showing the stable reentrant circuit in the RAA. The earliest activation is marked in red (symbol: o). The latest activation is marked in blue (symbol: $x$ ). Data from a representative example of $A F$ attributable to activation from the stable reentrant site in the RAA (from heart \#1). B, Reentrant trajectory of 2 loops of earliest and latest activation and $C$, slow conduction zones at the edges of the trajectory of earliest and latest activation. Reentrant circuit trajectory along with patterns of lines (up to $6 \mathrm{~mm}$ in the panel with curvature angle between the lines and $>4$ times slower conduction at edges in propagation (highest curvature angles). Conduction patterns potentially because of patterns in fiber directions. $D$, Reentrant circuit trajectory of a circular reentry (established schematic model in the last decades). E, Redefined reentrant circuit trajectory along with patterns of lines and with curvature angle between the lines at $>4$ times slower conduction at edges in propagation. F, Conduction pattern lines potentially because of patterns in fiber directions. (Left panel) Schematic of fiber arrangement and abrupt changes in the fiber direction (cp. Spach et al. 1982). ${ }^{48}$ (Right panel) 
medRxiv preprint doi: https://doi.org/10.1101/2020.12.14.20248171; this version posted December 16, 2020. The copyright holder for this preprint (which was not certified by peer review) is the author/funder, who has granted medRxiv a license to display the preprint in perpetuity.

\section{Figure 3}

A) Initiation of reentry by multiple Increased slow conduction zones

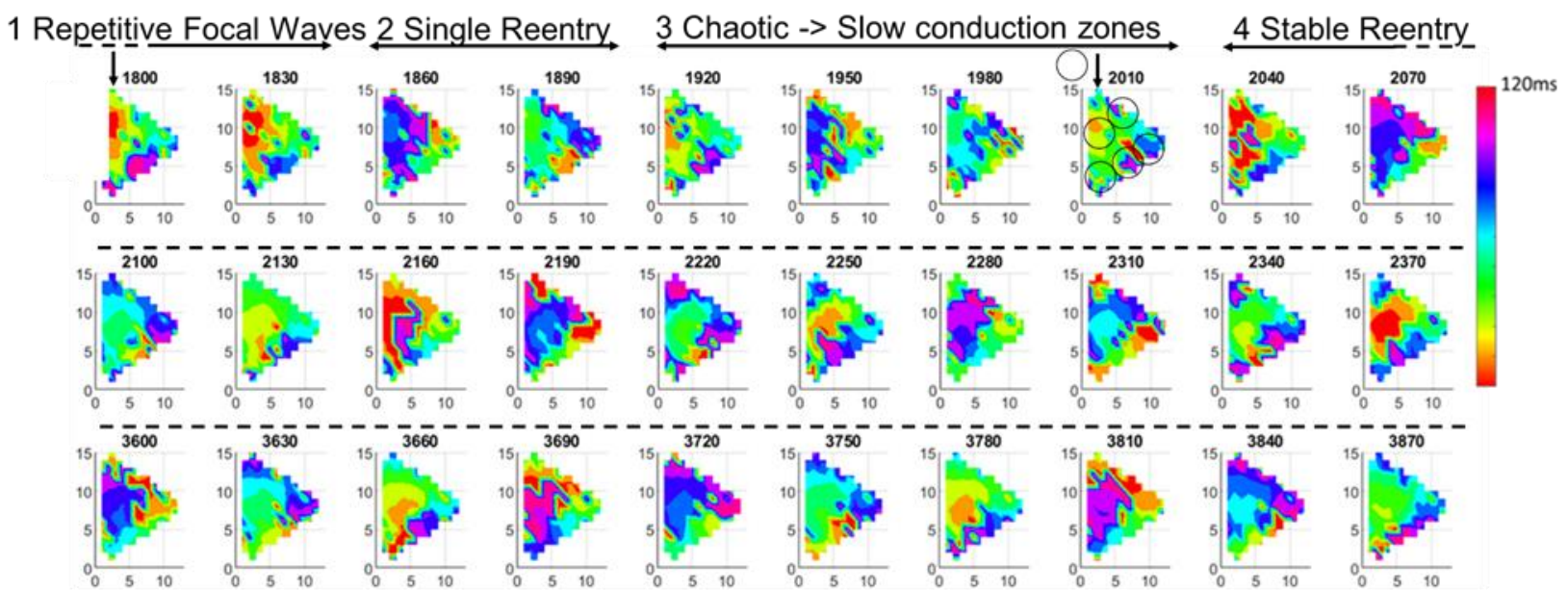
B) Maintenance of anchored reentry

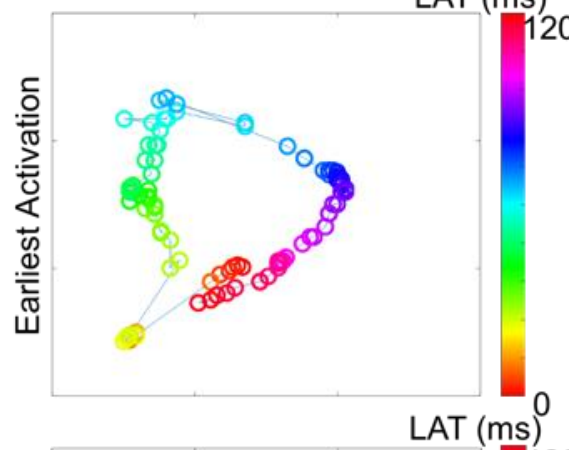

Activation delay (ms)

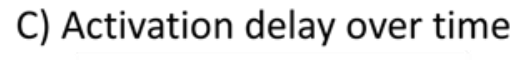

879

880

881

882

883

884

885

886

887

888

889

890
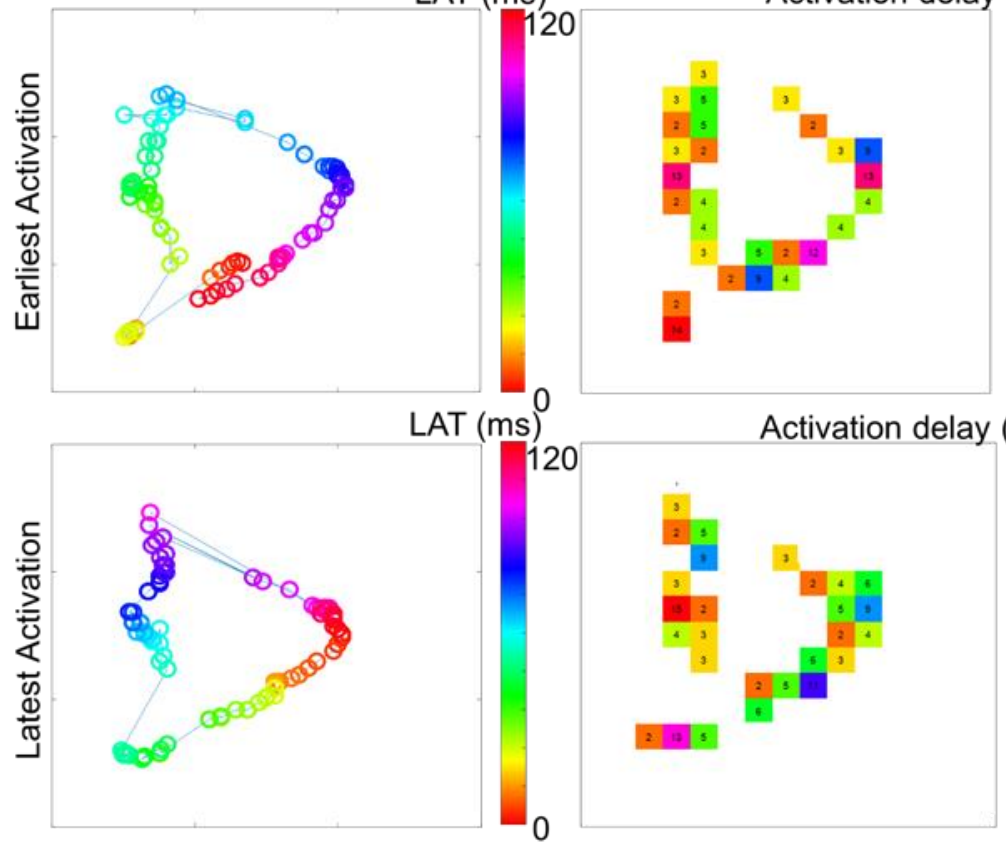

Activation delay $(\mathrm{ms})$

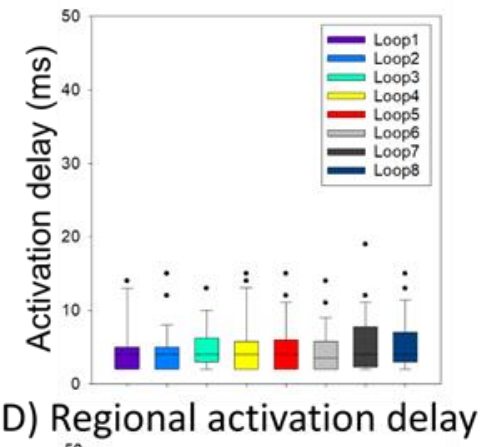

Figure 3: Initiation and maintenance of rotational activity between small slow conduction zones.

A, A representative example of the development stages of rotational activity over time consisting of varying activation pattern episodes in Heart \#7 in the region RAA: 1) Focal wave activation (1800-1830ms (further LAT maps of repetitive focal wave activation (600-1830ms) are given in the compare Supplemental Data)). 2) First instable reentrant loop (1860, $1890 \mathrm{~ms})$. 3) Chaotic activations (1920-2010 ms). 4) Stable rotational activity (2040 - 3870ms). B, Activation time maps, trajectory, and activation delay of earliest activation time in 2 reentrant loops. C, Activation delay over time in 8 following reentrant loops. D, Activation delay in the 6 different regions in reentrant loops of all animals.
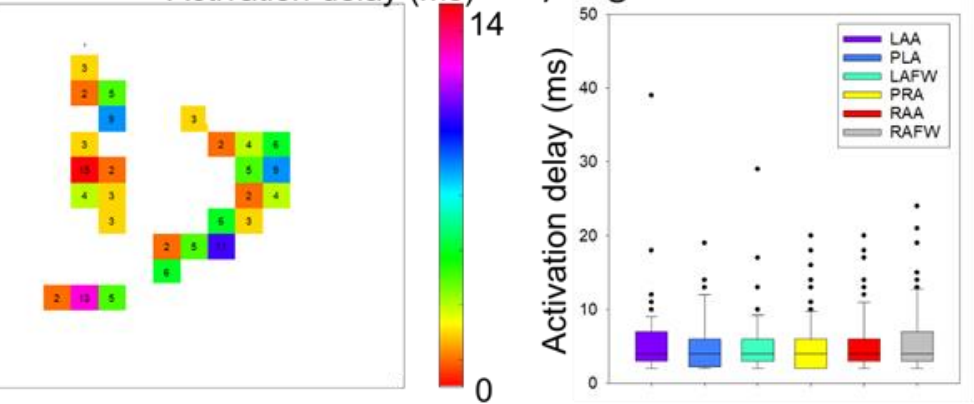
medRxiv preprint doi: https://doi.org/10.1101/2020.12.14.20248171; this version posted December 16, 2020. The copyright holder for this preprint (which was not certified by peer review) is the author/funder, who has granted medRxiv a license to display the preprint in perpetuity.

\section{Figure 4}

A) Termination of Anchored Reentry because of Cycle Length Variation

1) Stable Reentry CL $120 \mathrm{~ms}$ 2) Reentry CL $150 \mathrm{~ms}$
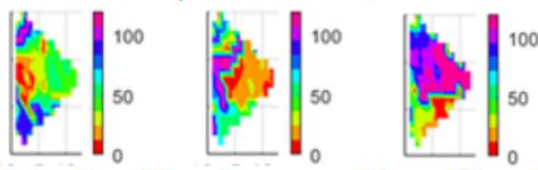

B) Episodes of Reentry versus Planar Wave Activation
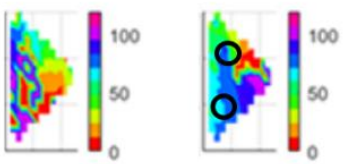

C) Rotational Activity versus Sinus Rhythm
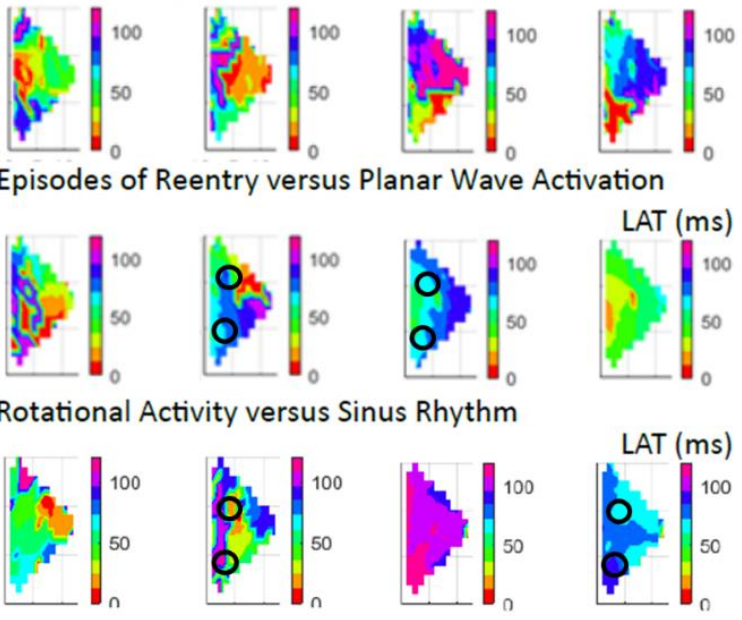

ion

892

893

894

895

896

897

898

899

900

901

902

903

904

905

906 locations in AF and SR. performed from the $L A A$.

Figure 4: Termination of rotational activity because of $\mathrm{CL}$ prolongation and similar slow conduction zone

A representative example of cycle length variation and the termination of stable reentry. Rotational activity with increasing CL over time in the RAA in heart \#10. (1) CL of $120 \mathrm{~ms}$ changed to (2) CL of $150 \mathrm{~ms}$ after 1.5 seconds rotational activity. After CL prolongation (3) rotational activity abruptly ended. $B, A$ representative example of rotational activity ( $C L=90 \mathrm{~ms}$ ) in LAT maps (30 ms steps) in the RAA in Heart \#10. (Left panel) The episode of rotational activity. (Right panel) More organized nearly planar wave episode ( $C L=120 \mathrm{~ms}$ ) in the same region (RAA) and animal. Slow conduction at the same location during rotational activity and planar wave activation. C, Overlapping slow conduction zones during AF (top panel) and sinus rhythm in the PLA. Activation delay increased by the factor 3-4 during AF compared to sinus rhythm or planar wave activation at slow conduction zones. CL increased from $120 \mathrm{~ms}$ to $150 \mathrm{~ms}$ (compare signal recordings). D, regional cycle length variations (standard deviation of $C L$ ) with the highest $C L$ variations in the right atrium. $E$, Decrease of activation delay (2x) when comparing AF with sinus rhythm/ pacing intervals (200ms to 500ms). The pacing was 
medRxiv preprint doi: https://doi.org/10.1101/2020.12.14.20248171; this version posted December 16, 2020. The copyright holder for this preprint (which was not certified by peer review) is the author/funder, who has granted medRxiv a license to display the preprint in perpetuity.

Figure 5

A) Thin simultaneous activation lines
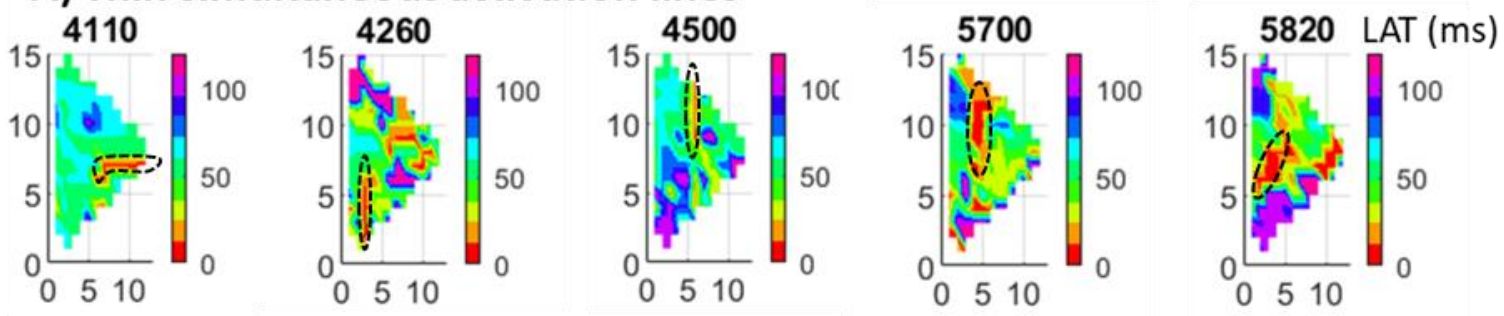

B) Focal activity along activation lines
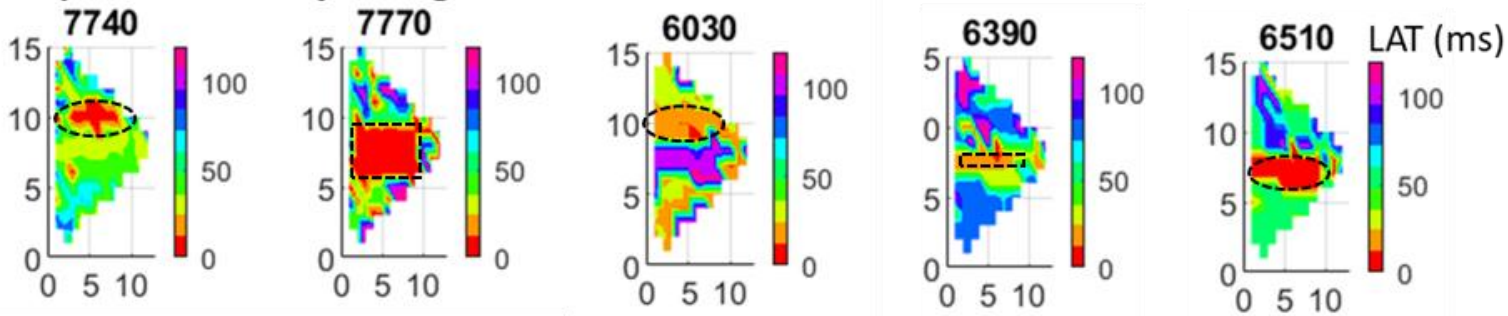

C) Figure of eight reentrant activity along activation lines
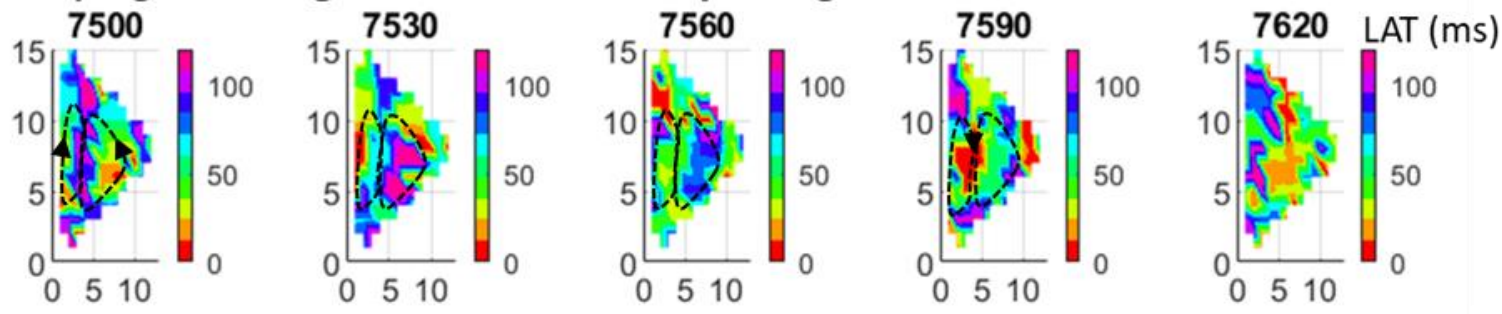

\section{D) Size and number of focal sources}

908

909

910

911

912

913

914

915

916

917

918
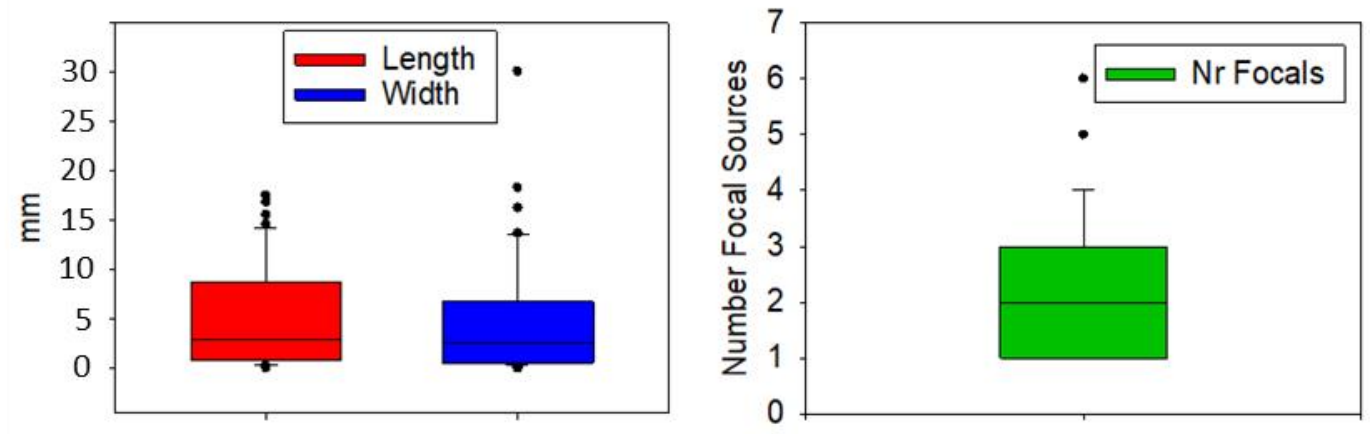

Figure 5: Different activation patterns along with activation lines.

A, A representative example (heart \#5) of thin simultaneous earliest activation (red in activation time maps, marked in black dashed line) along lines (size up to $2.5 \times 25 \mathrm{~mm}$ ) on the epicardial surface. B, Focal activity as simultaneous activation between activation lines, which were similar located (block dashed regions) over time episodes in LAT maps. Focal activities between line of blocks (up to $25 \mathrm{~mm}$ ) were frequently observed at the same locations potentially because of simultaneous activation in fiber lines. C, Figure of eight activation along activation lines in the PRA in heart \#5 frequently observed at the same location (marked with black dashed lines). D) Dimension (length and width) of focal sources detected as simultaneous earliest activation in $5 \mathrm{~ms}$ and number of focal sources per AF cycle. 
medRxiv preprint doi: https://doi.org/10.1101/2020.12.14.20248171; this version posted December 16,2020 . The copyright holder for this preprint (which was not certified by peer review) is the author/funder, who has granted medRxiv a license to display the preprint in perpetuity.

\section{A) Histological Tissue Sections}
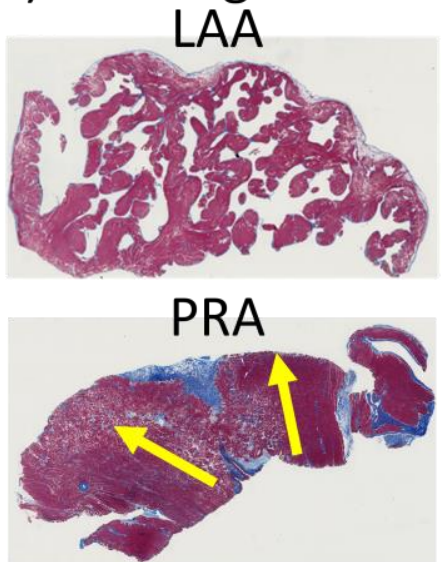

B)

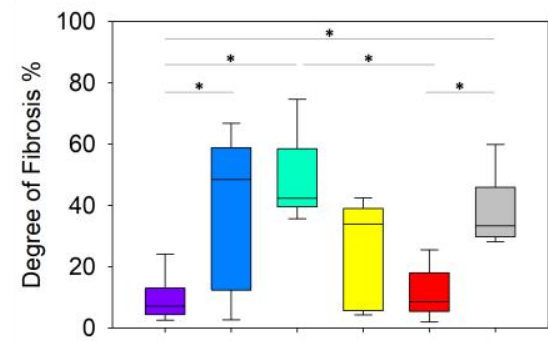

D)

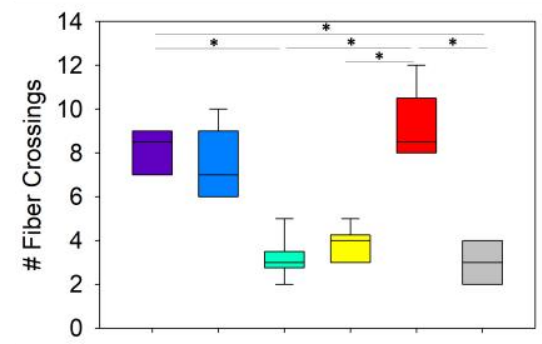

PLA

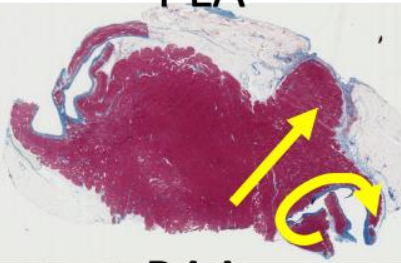

RAA

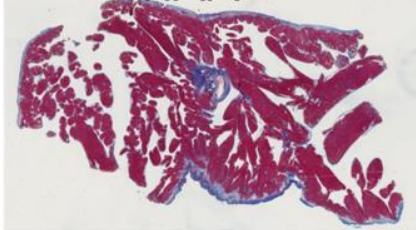

C) Fiber Orientation

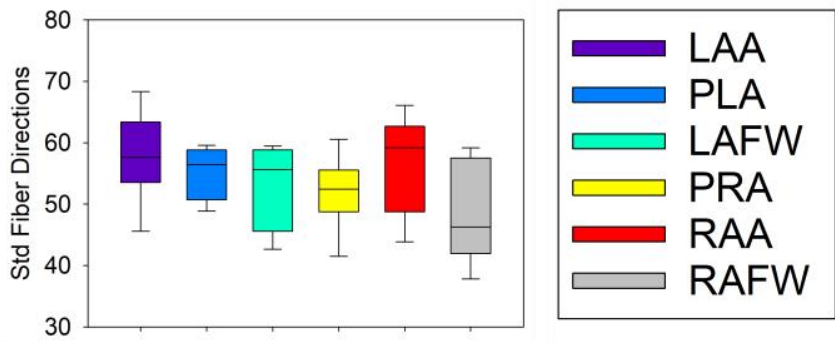

E) Rotational Activity VS Fiber Crossings

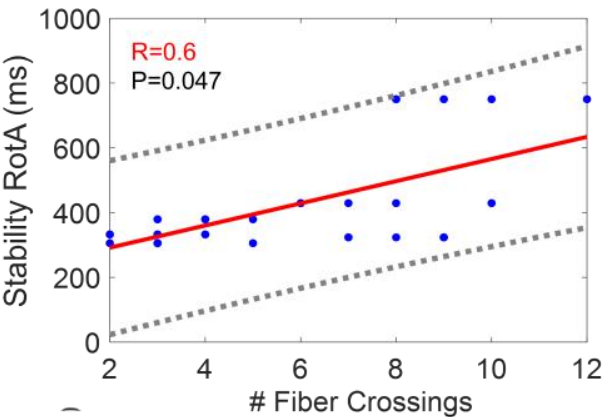

F)\#Fibrosis/Fat in Sections G) Fibrosis/ Fat \& Fiber Crossings
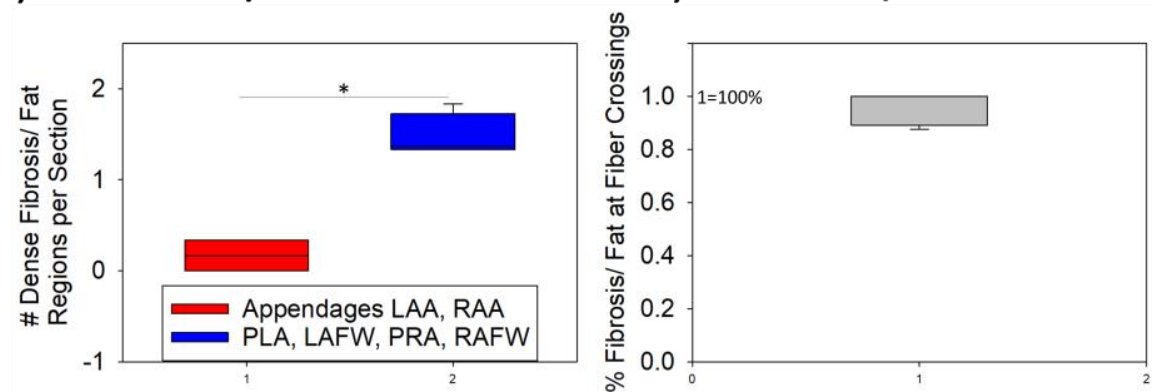

Figure 6: Substrate characteristics and correlation of rotational activity with fiber crossings density. 
medRxiv preprint doi: https://doi.org/10.1101/2020.12.14.20248171; this version posted December 16, 2020. The copyright holder for this preprint (which was not certified by peer review) is the author/funder, who has granted medRxiv a license to display the preprint in perpetuity. All rights reserved. No reuse allowed without permission.

922 A, Masson's trichrome stained tissue section. in the 6 bi-atrial regions: left atrial appendage (LAA), posterior 923 left atrium (PLA), left atrial free wall (LAFW), posterior right atrium (PRA), right atrial appendage (RAA), right 924 atrial free wall (RAFW). Fiber orientations are marked in yellow. Dense focal fibrosis developed at fiber crossings 925 (intersections of fiber lines). B, Degree of focal fibrosis in all bi-atrial regions. The highest focal fibrosis was 926 detected in the PLA and LAFW. C, Fiber isotropy index in all bi-atrial regions. The highest anisotropy was 927 detected in the PLA, LAA, and in the right atrium in the RAA ( $P$-value non-significant). $D$, The highest number of 928 fiber crossings were detected in the RAA, LAA, and PLA. E, Correlation of fiber crossings with the stability of 929 rotational activity. F, Number of detected dense fibrosis/ fat regions in each tissue section. Nearly no dense 930 fibrosis/fat regions were detected in the appendages, but about 1.5 in the other atrial regions. G, More than $93190 \%$ of the detected fibrosis and fat regions were located near fiber crossings in the atrial regions. $P<0.05$ for 932 all comparisons.

933

934

935 
medRxiv preprint doi: https://doi.org/10.1101/2020.12.14.20248171; this version posted December 16, 2020. The copyright holder for this preprint (which was not certified by peer review) is the author/funder, who has granted medRxiv a license to display the preprint in perpetuity.

Effect of PVI on Remote Regions

A) Cycle Length

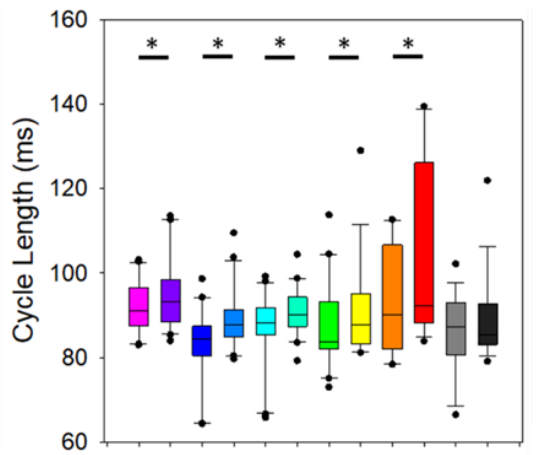

C) Change of Slow Conduction Zones

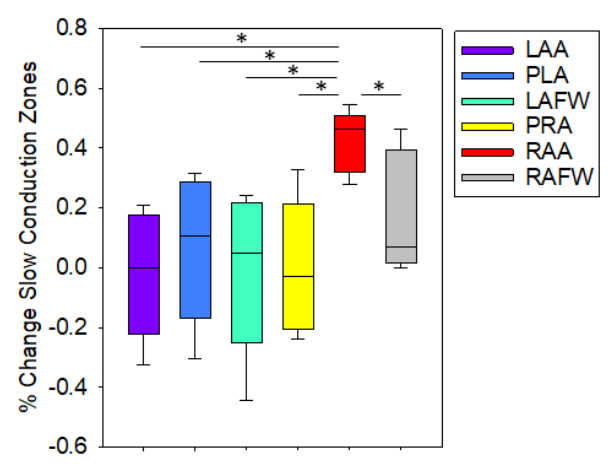

938

939 Figure 7: Effects of PVI on Regions remote to the PVs.

940

941

942

943

944

B) Stability Rotational Activity

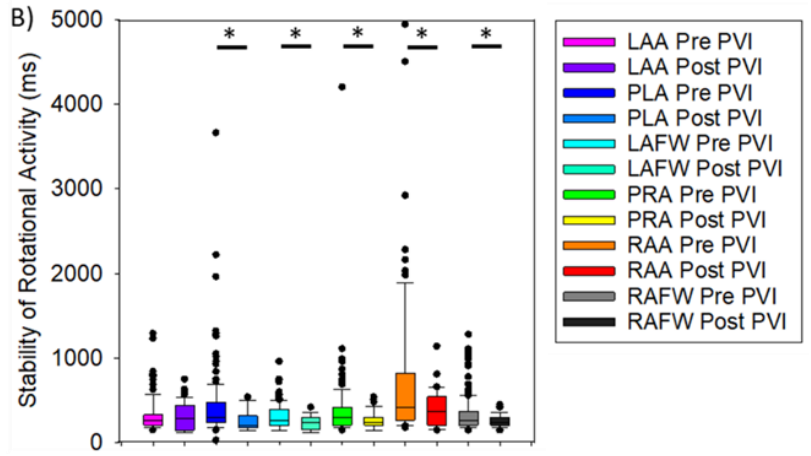

D) Rotational Activity vs Change of Slow- Conduction after PVI

E) \# Fiber Crossings vs Change of Slow-Conduction after PVI
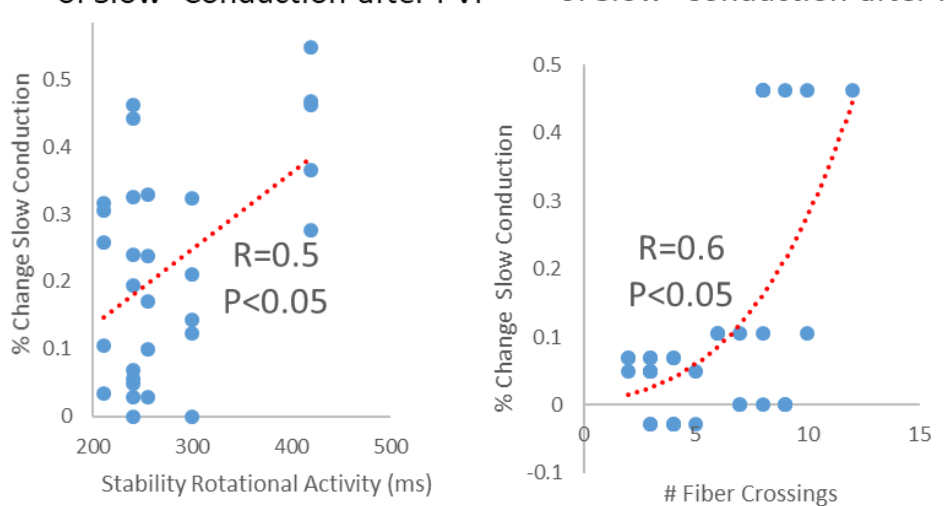

\# Fiber Crossings

$A, P V I$ led to a significant increase in $C L$ in nearly all regions remote to the PVs. B, Stability of rotational activity decreased significantly (baseline vs after PVI) in nearly all atrial regions. C, Change of slow conduction zones (>10ms activation delay) pre vs post PVI in \%. D, The percentage reduction change (range $0-60 \%$ ) of slow conduction zones pre vs post $P V I$ correlated with the stability of rotational activity at baseline $(R=0.5, P=0.005)$. E, Number of fiber crossings per tissue sections vs change of slow conduction after PVI. 
medRxiv preprint doi: https://doi.org/10.1101/2020.12.14.20248171; this version posted December 16, 2020. The copyright holder for this preprint (which was not certified by peer review) is the author/funder, who has granted medRxiv a license to display the preprint in perpetuity.
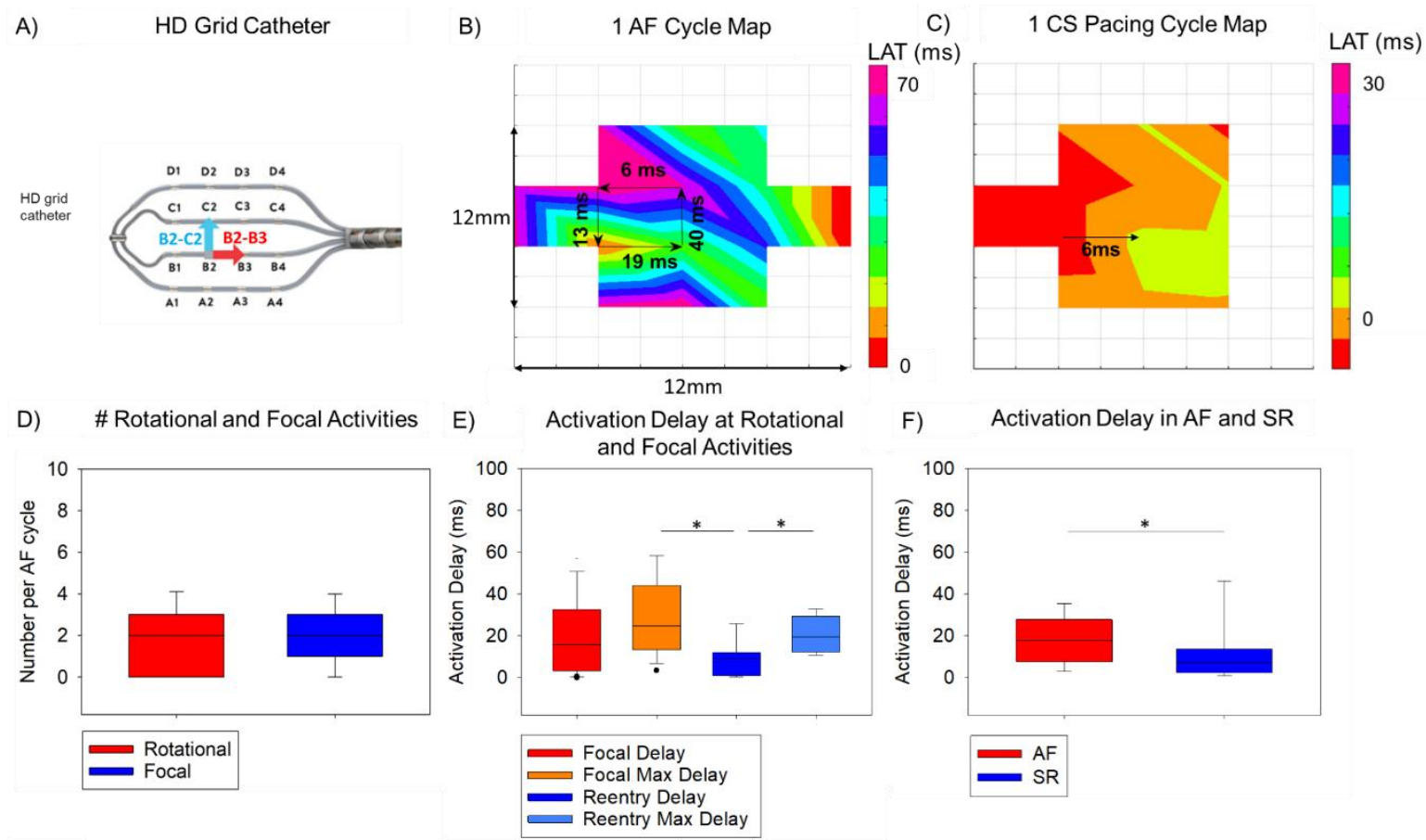

G)
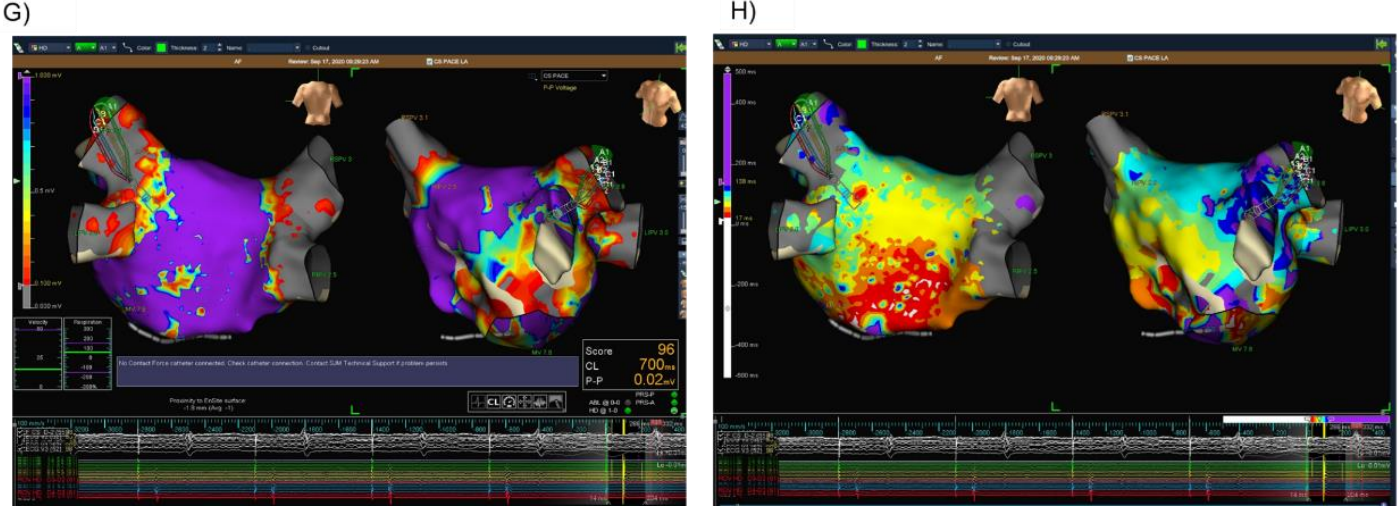

Figure 8 Clinical Evaluation of AF Drivers and Slow Conduction Zones in the LA in Persistent AF Patients.

$A$, Clinical left atrial evaluation of AF drivers and slow conduction zones in persistent AF patients using the clinical A) HD- grid catheter with 16 electrodes (interelectrode distance of $2.5 \mathrm{~mm}$ ). 24 bipolar signals recordings between the 16 electrodes of the HD grid catheter. Vertical bipolar recording marked in blue (y-direction). Horizontal bipolar electrodes marked in red (x-direction). B, Activation time map of 1 AF cycle showing a reentrant circuit with increased activation delay (40ms) at one trajectory segments (2-6 fold higher compared to the other 3 trajectory segment parts). C, Activation time map of 1 CS-pacing measurement with the HD-grid catheter showing about $2 x$ smaller activation delays compared to AF. D, Analysis of detected reentries, focal waves per AF cycle. E, Analysis of activation delay and maximal activation delay at focal sources $20.2 \pm 19.1 \mathrm{~ms}$ (median $15.7 \mathrm{~ms}$ ) and $26.8 \pm 17.4 \mathrm{~ms}$ (median $24.4 \mathrm{~ms}$ ) and activation delay and maximal activation delay at reentries $9.3 \pm 8.8 \mathrm{~ms}$ (median $9.2 \mathrm{~ms}$ ) and $20.2 \pm 8.1 \mathrm{~ms}$ (median $19.6 \mathrm{~ms}$ ) and. F, Activation delay in AF and SR showing $2 x$ higher activation delay in AF compared to CS-pacing/SR. G, Bipolar voltage map and corresponding $H$, activation time map in Ensite NavX mapping system ${ }^{\circledR}$ (Abbott). 
medRxiv preprint doi: https://doi.org/10.1101/2020.12.14.20248171; this version posted December 16, 2020. The copyright holder for this preprint (which was not certified by peer review) is the author/funder, who has granted medRxiv a license to display the preprint in perpetuity.

\section{$964 \quad$ Figure 9}

A)

\begin{tabular}{|c|c|c|c|c|}
\hline & \multirow{2}{*}{$\begin{array}{l}\text { Anatomic Reentry } \\
\text { Circus Movement } \\
\\
\mathrm{WL}=\mathrm{CV} \times \mathrm{RP}\end{array}$} & \multicolumn{2}{|c|}{ Functional Reentry } & \multirow{2}{*}{$\begin{array}{l}\text { Structural and } \\
\text { Functional Reentry } \\
\text { Polygon Reentry }\end{array}$} \\
\hline & & Leading Circle & Spiral Wave & \\
\hline $\begin{array}{l}\text { Determinant of circuit } \\
\text { size }\end{array}$ & Anatomical obstacle & $C V \times R P$ & Source-sink relationship & $\begin{array}{l}\text { Propagation preferred } \\
\text { along fiber line } \\
\text { directions, } \\
\text { Anchoring between } \\
\text { small slow conduction } \\
\text { zones at fiber crossings, } \\
\text { fibrosis }\end{array}$ \\
\hline Fixed circuit? & Yes & No & No & $\begin{array}{l}\text { Frequently anchoring at } \\
\text { same locations }\end{array}$ \\
\hline $\begin{array}{l}\text { Resetting and } \\
\text { entrainment? }\end{array}$ & Yes & No & ? & $\begin{array}{l}\text { Because of small slow } \\
\text { conduction zones } \\
\text { frequency dependent. }\end{array}$ \\
\hline Excitable gap? & Yes & No & Yes & Yes \\
\hline Core & $\begin{array}{l}\text { Anatomic obstacle, } \\
\text { Unexcitable }\end{array}$ & $\begin{array}{l}\text { Refractory tissue, } \\
\text { Unexcitable }\end{array}$ & Excitable but unexcited & $\begin{array}{l}\text { Not main reason for } \\
\text { anchoring, Slow } \\
\text { conduction edges } \\
\text { anchor reentry. }\end{array}$ \\
\hline Revolution time & $1 / \mathrm{CV}$ & RP & $\begin{array}{l}\text { Determined by } \\
\text { excitability properties }\end{array}$ & $\begin{array}{l}\text { Determined by structural } \\
\text { and functional properties } \\
\text { quantified by activation } \\
\text { delay characteristics like } \\
\text { value, size, number of } \\
\text { high activation delays. }\end{array}$ \\
\hline
\end{tabular}

B)

Small Slow Conduction Zones

\begin{tabular}{|c|c|}
\hline \multirow[t]{2}{*}{ Substrate } & Are Fiber crossings in all bi-atrial regions \\
\hline & Develop to zones of focal fibrosis and fat \\
\hline \multirow{2}{*}{$\begin{array}{r}\text { Activation delay in } \\
\text { activation time maps }\end{array}$} & Are frequency dependent zones of activation delay \\
\hline & Are anchor zones of rotational activities \\
\hline \multirow{3}{*}{$\begin{array}{l}\text { Dependency of activation } \\
\text { patterns, cycle length and } \\
\text { rhythm }\end{array}$} & Increase during rotational activity in $\mathrm{AF}$ \\
\hline & Reduce during planar wave activation in $\mathrm{AF}$ \\
\hline & Are at the same locations during AF and sinus rhythm \\
\hline Treatment with PVI & Reduce after PVI in all regions remote to the PVs \\
\hline Evaluation & Are detected in human like large animals and patients \\
\hline
\end{tabular}

Evaluation

Are detected in human like large animals and patients

966 Figure 9 Summary figure of novel reentry model and key findings.

967 A, Reentry models circus movement, leading circle, spiral wave, and new models of reentry along line (polygon) 968 patterns. In the circus movement, the anatomic reentry is around a fixed obstacle and allows for an excitable 969 gap. In the leading circle reentry model, the conduction velocity (CV) and refractory period (RP) determine the 
medRxiv preprint doi: https://doi.org/10.1101/2020.12.14.20248171; this version posted December 16, 2020. The copyright holder for this preprint (which was not certified by peer review) is the author/funder, who has granted medRxiv a license to display the preprint in perpetuity. All rights reserved. No reuse allowed without permission.

970 circuit size. Also, the center of the circuit is maintained refractory by centripetal wavelets. The spiral wave model 971 describes a curved wavefront with a core the so-called phase singularity (PS) which rotates around an excitable 972 but unexcited core. In contrast to the previous models, the new model describes both structural and functional 973 characteristics with slow conduction zones at the edges of propagation line patterns. Previous models focused 974 on the tip of the rotational activity analyzing the core with phase singularity points in phase maps. The focus in 975 the new model is in contrast to the previous models the earliest and latest activation within activation time 976 maps. B, Summary figure of this study. Small slow conduction zones ( $>3 \mathrm{~mm}$ ) were zones of fiber crossings in all 977 bi-atrial regions. At these fiber crossings zones, focal fibrosis and fat tissue developed. These fiber crossing zones 978 were frequency-dependent zones of activation delay and rotational activity anchored between these zones. 979 These zones were located at the same locations in different rhythms or activation patterns (AF and sinus rhythm, 980 rotational activity, and planar wave activation). Activation delay increased at these zones during rotational 981 activity and decreased during planar wave activation or sinus rhythm. PVI increased CL and reduced the 982 activation delay of these zones in all regions remote to the PVs. These activation delay zones at rotational 983 activities were present in the animal model and patients. These findings result in a proposed new model for 984 reentry. In contrast to the previous models, the new model describes both structural and functional 985 characteristics with slow conduction zones at the edges of propagation line patterns. Previous models focused 986 on the tip of the rotational activity analyzing the core with phase singularity points in phase maps. The focus in 987 the new model is in contrast to the previous models the earliest and latest activation within activation time 988 maps. 